NOTES

\title{
THE EXALTATION OF PRIVACY DOCTRINES OVER PUBLIC INFORMATION LAW
}

\author{
CHRISTOPHER P. BEALL
}

\section{INTRODUCTION}

Early last year, reporter Russell Carollo at the Dayton Daily News picked up the scent of a story that his instincts told him would knock the Sunday morning socks off his readers, a story that would ripple all the way to Capitol Hill. ${ }^{1}$ Mr. Carollo had noticed that strikingly large numbers of the men in the nation's military prisons were sex offenders. This tidbit of information eventually led to a five-day series of stories about how the military branches routinely allow service members to avoid conviction or serious prison time for sex offenses. The newspaper series showed the military justice system to be far more lenient than the civilian judicial system in dealing with sex offenders. Newspapers across the country published excerpts of the series; it earned accolades for Mr. Carollo and his colleagues, and it led to calls for congressional oversight hearings in Washington.

It did not, however, change the military's mind about public access to information concerning the military justice system. Mr. Carollo had researched his stories, in part, by filing numerous requests under the Freedom of Information Act (FOIA) for data regarding the military's handling of criminal sex offense charges. Much of the information he obtained from the Air Force was helpful; most of the information from the Navy and Army, however, was riven with redactions and wholesale withholdings of entire documents. The Navy, for example, supplied the records of courts-

1. The details of the following anecdote are taken from the Dayton Daily News' coverage in its series "Military Secrets," which appeared Oct. 1 through Oct. 5, 1995. Particularly relevant stories in that series were Russell Carollo, Escaping Justice: Sex Offenders Find Lenient Treatment in Military Justice System, DAYTON DAILY NEwS, Oct. 1, 1995, at 1A; Russell Carollo, Lawsuit Filed For Release of Records, DAYTON DAILY NEws, Oct. 1, 1995, at 7A; Max Jennings, Tenacious Investigating Pays Off, DAYTON DAILY NEws, Oct. 1, 1995, at 10B. 
martial-which are conducted in public-with the names of the defendants, witnesses who testified, and other significant information deleted. The Navy later argued that the names of the defendants could not be revealed after the public trials because the privacy interests of the defendants outweighed any public interest in disclosure. ${ }^{2}$

Nevertheless, Mr. Carollo tracked down the necessary information by consulting local bar associations to find the plione numbers of lawyers listed in the transcripts. Despite the Navy's redactions, Mr. Carollo provided extensive details about sex offense cases the Navy had refused to discuss publicly. For example, one of the journalist's stories recounted a case in which four Navy seamen had sex with 13- and 15-year-old girls during a port visit in Sitka, Alaska. The men were accused of sexual assault, but Navy officials decided not to prosecute in part because the sailors claimed they were not aware that the girls were underage. Despite these and otlier revelations in the Dayton Daily News, the Navy contimues to fight the FOIA suit filed by the newspaper. ${ }^{3}$

Around the same time that Mr. Carollo was wrestling with the military over FOIA disclosures, two reporters in Nortli Carolina were conducting a different kind of hunt for information. ${ }^{4}$ Journalists Pat Stith and Tinker Ready relied on their state's public records law ${ }^{5}$ to search for information in the records of North Carolina's chief medical examiner. The reporters were tracking information on all deaths classified as "misadventures," an autopsy classification mdicating fatal medical mistakes by doctors. They were able to compile information detailing a total of 131 deaths by misadventure between 1989 and 1993 .

2. Russell Carollo, Navy to Deny Public News of Courts-Martial, DAYTon DaILY NEwS, Oct. 22, 1995, at 1A.

3. In December 1995, the Navy released portions of the information sought by the Dayton Daily News in its FOIA suit, but the Navy continues to refuse to release the names of witnesses who testify at the military's courts-martial. Russell Carollo \& Jeff Nesmith, Army, Navy to Release Case Records, DaYton Dally NEws, Dec. 8, 1995, at 10A. No decisions have been reported in this FOIA case, but it is docketed as Dayton Newspapers, Inc. v. Department of the Navy, No. C-3-95-328 (S.D. Ohio filed Aug. 24, 1995).

4. The details of this anecdote were taken from a series of stories published in the News \& Observer of Raleigh, N.C., during July and August of 1995. The most relevant stories are Tinker Ready \& Pat Stith, Fatal Medical 'Misadventures' Kept Under Wraps, News \& OBSERVER, July 16, 1995, at A1; Pat Stith, State Board to Gather Records of Fatal Medical Errors, News \& OBSERVER, July 21, 1995, at A1.

5. N.C. GEN. STAT. § 132 (1995). 
Their stories revealed not only who the victims were and how they died, but also the hospitals where the deaths occurred. None of the information provided in the inedical examiners' reports was redacted. Furthermore, in some cases, the reporters discussed the findings of inedical misadventures with the families of the victims. The stories also demonstrated that the state board responsible for keeping track of doctor certifications had failed to momitor the records of misadventures. In soine cases, board meinbers were unaware that the state agencies kept such records.

These two anecdotes highlight some of the stark differences in scope and utility between state pubhic records laws and the federal FOIA. ${ }^{6}$ For many FOIA users, the Act has not lived up to its billing as a citizen's tool to hold government officials accountable. Instead, it has become a morass of cumbersoine doctrimes and frustrating procedural delays.

Part I of this Note will examine some of the recent FOIA decisions that reveal an imderlying philosophy about the Act. These cases will show that federal courts today apply a set of principles-best identified as the "central purpose doctrine"-to restrict disclosure of government information. "Moreover, the cas-

6. FOIA creates a broad presumption of access to the "records" of any federal "ageucy." See 5 U.S.C. \& 552(a)(3) (1994). The Act, though, is subject to nine exemptions which sometimes seem to swallow the presumption whole. See \& 552(b). Those exemptions are generally for documents:

(1) Classified as secret becanse of uational defense or foreign policy.

(2) Related to internal agency "personnel" practices.

(3) Specifically exempted from disclosure by another statute.

(4) Containing confidential commercial or financial information, or trade secrets.

(5) Containing legally privileged or dehberative-process information.

(6) Containing private personal or medical information.

(7) Involving law enforcement investigations, and whose disclosure

(A) would interfere with ougoing investigations;

(B) would interfere with a fair trial;

(C) could result in an invasion of privacy;

(D) could disclose a confidential source;

(E) would disclose law enforcement techniques; or

(F) could endanger the safety of law enforcemeut personnel.

(8) Involving bank examinations.

(9) Involving some aspects of oil and natural gas wells.

Id.

7. The courts have not acknowledged such a doctrine in so many words. Instead, a group of commentators coined the term 'central purpose doctrine' in a 1994 article argning for a much broader application of the primciples. Fred $\mathrm{H}$. Cate et al., The Right to 
es discussed in Part II will show that despite the rule that the exemptions of FOIA inust be narrowly construed, ${ }^{8}$ the central purpose doctrine shows signs of overwhelming the entire field of FOIA jurisprudence, primarily because it allows courts to place privacy interests ahead of the interests favoring disclosure. Part III will examine why the few recent cases that have advanced public access to information are unlikely to alter the growing primacy of the central purpose doctrine. For comparison, Part IV of this Note will survey some of the recent amendments to state public records laws that show a much greater solicitude toward openness and disclosure of government inforination. These state amendınents indicate that when pohcy makers choose to define the legal status of government inforination as "property" belonging to the public at large, they ensure a more open approach to inforination access. Finally, Part V concludes with an examination of what one court called a "novel" legal question: What should a court do when a state public records law inandates disclosure by one-state agency, but FOIA apparently allows another federal agency to withhold the very same information? As demonstrated by such a collision between opposing philosophies of government information, there is a widening gap in the law's protection of a citizen's access to government information. That division is harmful not merely because it will lead to a less informed public, but also because it undermines the essential goal of public information law-to establish the people as governors over the government. ${ }^{9}$

Privacy and the Public's Right to Know: The "Central Purpose" of the Freedom of Information Act, 46 ADMIN. L. REV. 41, 67 (1994). This doctrine, traditionally applied only in cases implicating personal privacy rights, holds that government information should not be released unless it "will serve the purpose of ensuring that 'the Government's activities be opened to the sliarp eye of public scrutiny."' Id. (quoting United States Dep't of Justice v. Reporters Comm. for Freedom of the Press, 489 U.S. 749, 774 (1989)). The proposal by Professor Cate and his co-authors suggests that this doctrine slould be applied not just to privacy cases but to all FOIA cases. Id. This Note argues that federal courts increasingly have adopted Professor Cate's proposal for a broader application of the central purpose doctrine without formally recognizing the doctrine by name. See discussion, infra section II.C.

8. See Department of the Air Force v. Rose, 425 U.S. 352, 361 (1976) (stating that limited exemptions "do not obscure the basic policy that disclosure, not secrecy, is the dominant objective of the Act," and that these exemptions "nust be narrowly construed").

9. In the interest of full disclosure, the author notes that lie formerly was employed by newspapers in several states. As an investigative journalist, lie pursued information requests under FOIA and the state public records laws of Califormia, Nevada, North Carolina, and Rhode Island. 


\section{CONTROLLING ACCESS TO INFORMATION THROUgh FOIA'S \\ CENTRAL PURPose Doctrine}

\section{A. A Doctrine Is Born}

One of the continuing themes spicing the reams of literature on FOIA has been the view that the Act opened a Pandora's jar $^{10}$ of unintended consequences. ${ }^{11}$ These so-called unintended consequences ostensibly include the very ills that prompted the Ford Administration to oppose the 1974 FOIA amendments-that FOIA procedures would cost too much and would overwhelm administrative agencies. ${ }^{12}$ Some commentators have faulted FOIA for providing disclosure to the "wrong" people, sucl as businesses, hitigants, convicted felons, and political terrorists. ${ }^{13}$ More recent

10. See Robert GRAves, THE GREeK MYTHS § 39(j) (Penguin Books) (1955) (recalling Hesiod's fable that Pandora opened the jar (not box) in which Prometheus had imprisoned all the Spites that might plague mankind, such as Old Age, Labor, Sickness, Insanity, Vice, Passion, and Delusive Hope).

11. The seminal work that posited this complaint about unintended consequences came from then-Professor Antonin Scalia, who noted in his now often-quoted epigranı that FOIA is "the Taj Mahal of the Doctrine of Unanticipated Consequences, the Sistine Chapel of Cost-Benefit Analysis Iguored." Antonin Scalia, The Freedom of Information Act Has No Clothes, Regulation, March/April 1982, at 15. In her defense of FOIA, Circuit Judge Patricia Wald conceded Professor Scalia's premise that the law had created a host of unintended consequences. See Patricia M. Wald, The Freedom of Information Act: A Short Case Study in the Perils and Paybacks of Legislating Democratic Values, 33 EMORY L.J. 649, 664-69 (1984). Yet Judge Wald called these consequences the "price" of freedom: "FOIA, like all basic freedoms, sometimes hurts the worthy and sometimes helps the imworthy." Id. at 683.

Other commentators, however, have found the costs of these unintended consequences to be too high:

The inescapable conclusion is that the criminal element, particularly organized crime, has learned to detect informant identities and the status of investigations by sifting through sensitive records obtained via FOIA requests. . . . To state the extreme cases, taxpayers now subsidize requests from foreign corporations spying on U.S. companies, from imprisoned felons trying to discover who put thein behind bars, and from organized crime groups trying to avoid detection.

Orrin Hatch, Refinements Are Needed to Stop Abuses, 69 A.B.A. J. 556, $556-57$ (1983); see also Alfonse M. D'Amato \& Antomia M. Greenınan, The Freedom of Information Act and the CIA: How S. 1235 Will Enhance Our Nation's Security, 9 J. OF LEGIS. 179, 182-83 (1982) (arguing that the Act had allowed the disclosure of information that had threatened the lives of U.S. agents abroad and national security interests at home).

12. See H.R. REP. No. 876, 93d Cong., 2d Sess. 15-24 (1974), reprinted in 1974 U.S.C.C.A.N. 6267, 6276-85 (reprinting letters detailing the opposition of the Departments of Justice and Defense to the FOIA amendments).

13. See D'Amato \& Greeninan, supra note 11, at 182-83; Hatch, supra note 11, at 557; Karen A. Winchester \& James W. Zirkle, Freedom of Information and the CIA Information Act, 21 U. RICH. L. REV. 231, 232-36 (1987) (arguing that amendments to 
commentators have noted that the tremendous onslaught of FOIA requests received by federal agencies imposes dramatic costs on the budgets and personnel of those agencies. ${ }^{14}$ The essential view of many FOIA critics seems to be that FOIA simply is too much of a good thing. ${ }^{15}$ They argue that the public should not be

FOIA were badly needed). See generally Benjamin S. DuVal, Jr., The Occasions of Secre$c y, 47$ U. PrTT. L. REv. 579 (1986) (arguing that greater government secrecy and further restrictions on access to government information are appropriate and justifiable under the First Amendment). Despite the vehement criticism of FOIA as being too generous in its disclosure provisions, the majority of the literature on FOIA has argued that FOIA and the judicial interpretations of it are not generous enough. A short but illustrative sampling of the law review articles advocating a more generous approach to information access includes Danae J. Atchison, Comment, Reigning in the Glomar Response: Reducing CIA Abuse of the Freedom of Information Act, 27 U.C. DAVIS L. REv. 219 (1993); Jerry J. Berman, The Right to Know: Public Access to Electronic Public Information, 3 SOFrWARE L.J. 491 (1989); Deckle McLean, Privacy Gaining Heft as an FOIA Exemption, 15 COMM. \& L. 25 (1993); Sean E. Andrussier, Note, The Freedom of Information Act in 1990: More Freedom for the Government; Less Information for the Public, 40 DUKE L.J. 753 (1991); Note, Keeping Secrets: Congress, the Courts, and National Security Information, 103 HARV. L. REV. 906 (1990).

14. See Eric J. Sinrod, Freedom of Information Act Response Deadlines: Bridging the Gap Between Legislative Intent and Economic Reality, 43 AM. U. L. REV. 325, 333-42 (1994) (reporting that backlogs in FOIA requests have slowed information access at virtually every federal agency, and the government's cost of processing all FOIA requests in 1991 were pegged at \$91,405,744); Michael Moss, Public Eye: Federal Service Gets Wider Use by Sleuths, Snoops and Senators, WALl STREeT JouRNAL, Jan. 3, 1995, at A1 (reporting that the cost of processing FOIA requests in 1992, the latest year available, was $\$ 108$ million, while the government collected only $\$ 8$ million in fees); see also Michael M. Lowe, Note, The Freedom of Information Act in 1993-1994, 43 DUKE L.J. 1282, 1283-85 (1994) (discussing the slim prospects that agencies wonld receive more resources to deal with FOIA costs).

The multi-million-dollar cost of processing FOIA requests stands in stark contrast to the original congressional estimate of the costs: The House Committee on Government Operations agreed in 1974 that the annual costs of the program would be $\$ 50,000$ in the first year and $\$ 100,000$ per year thereafter for five years. See H.R. REP. No. 876, supra note 12, at 6275. Today, not only have the costs of the FOIA program exceeded the expectations of the 1974 Congress, but the 10-day time limits imposed by that Congress no longer have any significance. See Cecola v. FBI, No. 94-C4866, 1995 WL 549066 (N.D. IIl. Sept. 8, 1995) (holding that a six-year delay in processing a FOIA request did not violate the Act's time limits; the delay was warranted by the "extraordinary circumstances" of the FBI's backlog of FOIA requests).

15. See, e.g., Patrick E. Cole, The Freedom of Information Act and The Central Intelligence Agency's Paper Chase: A Need for Congressional Action to Maintain Essential Secrecy for Intelligence Files While Preserving the Public's Right to Know, 58 NOTRE DAME L. REV. 350 (1982) (arguing that contemporary FOIA provisions provided too much access to the government's intelligence files); cf. George B. Trubow, Protecting Informational Privacy in the Information Society, $10 \mathrm{~N}$. ILL. U. L. REV. 521, 521-23, 527-31 (1990) (discussing the need to enhance privacy protection under federal law and applauding the decision in United States Dep't of Justice v. Reporters Comm. for Freedoin of the Press, 489 U.S. 749 (1989) as providing a useful doctrine to prevent disclo- 
trusted to restrain its overwhelming temptation to ravage the mountains of information stored in government warehouses. Some rationale or some doctrine was needed to protect the public from its own worst inclinations to exploit the intoxicating availability of information.

1. The Reporters Committee Case. In the midst of this academic and political hand-wringing, the Supreme Court delivered what came to be seen as a set of guiding principles in Department of Justice v. Reporters Committee for Freedom of the Press ${ }^{16}$ and its progeny ${ }^{17}$-principles best described as the Court's "central purpose" doctrine. The Court never identified this doctrine by such a naine. Instead, it identified the principles as a way of interpreting the asserted congressional intentions underlying FOIA. Since its decision in Reporters Committee, the Court has repeated these principles in ways that indicate a unifying ideology, a doctrine, about the purposes of FOIA. This notion of a "central purpose" underpinning the Act-a notion distilled by a virtually unanimous Court ${ }^{18}$ - was just the kind of doctrine the

sure of private information).

16. 489 U.S. 749 (1989).

17. See United States Dep't of Defense v. Federal Labor Relations Auth., 114 S. Ct. 1006 (1994); Department of State v. Ray, 502 U.S. 164 (1991). Both cases will be discussed infra section I.A.2-3. Sonie of the cases that have applied the central purpose doctrine in the courts of appeals include Jones v. FBI, 41 F.3d 238 (6th Cir. 1994); United States Dep't of the Navy v. Federal Labor Relations Auth., 975 F.2d 348 (7th Cir. 1992); Hunt v. FBI, 972 F.2d 286 (9th Cir. 1992); Hale v. Department of Justice, 973 F.2d 894 (10th Cir. 1992), vacated on other grounds, 113 S. Ct. 3029 (1993); Hopkins v. Department of Housing and Urban Dev., 929 F.2d 81 (2nd Cir. 1991); and Schwaner v. Department of the Air Force, 898 F.2d 793 (D.C. Cir. 1990).

18. Justice Stevens' opinion was joined by six justices: Chief Justice Rehnquist, and Justices Kennedy, Marshall, O'Connor, White, and Scalia. Reporters Committee, 489 U.S. at 750 . The concurrence by Justice Blackmun, joined by Justice Brennan, did not overtly dispute the majority's notion of a single "central purpose" of FOIA. Instead, Justice Blackmun rejected the majority's categorical assertion that, in all cases, disclosing FBI rap sheets would constitute an unwarranted invasion of personal privacy. Id. at 780 (Blackmnn, J., concurring) ("[T]he Court's use of 'categorical balancing' . . . is not basically sound.").

However, without actually saying so, Blackmun implicitly rejected the notion of a single central purpose under FOIA: Blackmun argued that an unwarranted invasion of privacy would not exist if the FBI disclosed the rap sheet of a congressional candidate. In such a case, Blackmun said, any invasion of privacy would be warranted. The private interest in privacy would be nonexistent because the "candidate relinquislied any interest in preventing the dissemination of this information when lie cliose to run for Congress." Id. Also, the pnblic interest in any criminal record of the potential Congressman would 
commentators had sought: a staunch and utilitarian bulwark against immoderation. Since its unveiling in 1989, the "central purpose" doctrine has done yeoman's work in the effort to restrain the public's access to government infornation. ${ }^{19}$

Before discussing the recent applications of the central purpose doctrine, the origins of its principles must be revisited. The doctrine originally was intended only as a tool for deternining the proper balance that courts should strike in FOIA cases involving the Act's privacy exemptions, Exemptions $6 \& 7(\mathrm{C}){ }^{20}$ The Court divined the rule in Reporters Committee from the midst of the controversy over whether the FBI's computerized compilation of arrest and conviction information, a person's "rap sleet," could be withheld under Exemption 7(C). ${ }^{21}$ The specific question before the Court was whether the disclosure of the rap slieet infornnation reasonably could be "expected to constitute an unwarranted invasion of personal privacy." 22 In Reporters Committee, the particular nature of a rap sheet complicated the public interest/private interest balancing test: A rap sheet comprises information that initially was in the public domain, a fact suggesting that the entire rap sheet itself also sliould be available to the public. ${ }^{23}$ The Court, lowever, resolved this first issue by rejecting as "cramped" the notion that a person loses his privacy interest in criminal history information merely because the information once had been a inatter of public record. ${ }^{24}$

be quite high. Thus, Blackmun's hypothetical example demonstrates that he believed there must be some kind of legitinate public interest beyond the simgle "central purpose" identified by the majority. Id.

19. See cases discussed infra part II.

20. See supra note 6.

21. Reporters Committee, 489 U.S. at 751.

22. Id. In every FOIA case that tests the contours of Exemption 7(C), a court must determine whether the potential invasion of privacy is "warranted" by weighing the public interest in disclosure against the private interest in secrecy. See 5 U.S.C. $\S 552(\mathrm{~b})(7)(\mathrm{C})$ (1994); see also Justin D. FRANKLIN \& RoBert F. BOUCHARD, 1 GUIDEBOOK TO THE FREEDOM OF INFORMATION AND PRIVACY ACTS § 1.10[3] (1995).

23. See Reporters Committee, 489 U.S. at 753.

24. Id. at 763. According to the Court's elaboration, a private citizen possesses a demonstrable privacy interest in the criminal history information becanse "[p]lainly there is a vast difference between the public records that might be found after a diligent search of courthouse files, county archives, and local police stations throughout the country and a computerized summary located in a single clearinghouse of infonnation." Id. at 764. 
The next issue involved an evaluation of the public interest at stake in the balancing test, and at this point, the Court developed its powerful central purpose doctrine. The media plaintiffs in $R e$ porters Committee argued before the Supreme Court that disclosing the information in the rap sheet for Charles Medico, a businessinan who was reputed to be a member of organized crime in Philadelphia, would serve a substantial public interest. The plaintiffs argued that disclosing Medico's rap sheet would confirm his alleged criminal background, and that this information was of public concern because Medico had dealings with a congressinan and his business had won contracts with the Department of Defense..$^{25}$ The Court, however, rejected these goals as "outside the ainbit of the public interest that the FOIA was enacted to serve". ${ }^{26}$

Conceivably Medico's rap sheet would provide details to include in a news story, but, in itself, this is not the kind of public interest for which Congress enacted the FOIA. In other words, although there is undoubtedly some public interest in anyone's criminal history, especially if the history is in some way related to the subject's dealing with a public official or agency, the FOIA's central purpose is to ensure that the Government's activities be opened to the sharp eye of public scrutiny, not that information about private citizens that happens to be in the warehouse of the Government be so disclosed. ${ }^{27}$

Elsewhere in the decision, the Court articulated this notion of a "central purpose" of FOIA by repeating language from an earlier case in which the Court had declared that "the basic purpose of the Freedoin of Information Act [is] "to open agency action to the light of public scrutiny."'"28 Whether the Court intended any significance in recliaracterizing the Rose phrase ("the basic purpose") into the later Reporters Committee phrase ("the central purpose") remaims an open question. The difference appears to lack any significance because even later in Reporters Committee, the Court

25. Reporters Committee, 489 U.S. at 774.

26. Id. at 775 .

27. Id. at 774 (emphasis added).

28. Id. at 772 (emphasis added) (quoting United States Dep't of the Air Force v. Rose, 425 U.S. 352, 372 (1976)). However, the crucial original language that first appears as a quotation in Rose and then again in Reporters Committee-that the purpose of the Act is "to open agency action to the light of public scrutiny"-has no original citation in Rose. It is an assertion without attribution. 
provided another permutation of the phrase, declaring that Congress had "expressed the core purpose of the FOIA as 'contribut[ing] significantly to public understanding of the operations or activities of the government."'29

Regardless of whether the idea is phrased as the "basic" purpose, the "central" purpose, or the "core" purpose, the Court's essential idea is that Congress did not intend for disclosure to be an end for its own sake. The touchstone of FOIA, according to the Court, is not to be freedoin of information, but rather a notion of good government. The Act provides citizens with the tools necessary to judge whether their government is performing according to their wishes. In the Court's view, FOIA is simply a means to an end, not an end itself. Arguably, the Court's position may be an incorrect reading of the central underpinning of the Act, ${ }^{30}$ but any disagreements today over the Court's interpretation are virtually academic: The Court twice has reaffirmed its view that the "central purpose" of FOIA is to serve "the citizens' right to be informed about 'what their government is up to."'31

2. The Ray Case. The first of these two subsequent cases, United States Department of State v. Ray, ${ }^{32}$ extended the central purpose doctrine to FOIA requests under Exemption $6 .{ }^{33}$ The FOIA request that prompted this case involved a Florida lawyer who sought copies of the State Departınent's summaries of interviews with Haitian refugees conducted at sea. ${ }^{34}$ The Court said that Exemption 6, like Exeinption 7(C), "requires the Court

29. Id. at 775 (emphasis added) (quoting 5 U.S.C. \& 552(a)(4)(A)(iii) (1994)).

30. See, e.g., Glenn Dickinson, Note, The Supreme Court's Narrow Reading of the Public Interest Served by the Freedom of Information Act, 59 U. CIN. L. REv. 191, 206-11 (1990) (arguing that the Reporters Committee rule is "basically flawed"). Additionally, Congress' articulation of the public imterest under FOIA was never so narrow as the formulations presented in Rose and Reporters Committee. See H.R. REP. No. 1497, 89th Cong., 2d Sess. 11 (1966), reprinted in 1966 U.S.C.C.A.N. 2418, 2428. Instead of limiting the public interest to information about agency actions, the House Committee on Government Operations said the "proper balance" for considering the purpose of the Act lies in "the preservation of the public's right to Government information." Id.

31. See United States Dep't of Defense v. Federal Labor Relations Auth., 114 S. Ct. 1006, 1012 (1994) (quoting Reporters Committee, 489 U.S. at 773); United States Dep't of State v. Ray, 502 U.S. 164, 177-78 (1991) (quoting Reporters Committee, 489 U.S. at 773).

32. 502 U.S. 164 (1991).

33. See id. at 177-78.

34. Id. at 168. 
to balance 'the individual's right of privacy' against the basic policy of opening 'agency action to the light of public scrutiny."'35 On the public interest side of the balance, the Court stated that the "cognizable" public interest encompassed information about "whether the State Department has adequately monitored Haiti's compliance with its promise not to prosecute returnees."36 The Court said the central purpose of FOIA justified the release only of the redacted interview summaries; it did not warrant releasing the names or identifying details of the refugees. ${ }^{37}$ The Court specifically rejected the proffered argument that knowing the names of the refugees would allow the plaintiffs to double-check the State Department's assurances that the refugees had not been mistreated after they were returned to Haiti. ${ }^{38}$

3. The Departinent of Defense Case. The Supreme Court's most recent FOIA case ${ }^{39}$ cemented the central purpose doctrine even further and, just as concretely, blocked any development of the "derivative-use" rationale for FOIA requests. In United States Department of Defense v. Federal Labor Relations Authority, the Court for the first time explicitly held that the one and only interest that would satisfy the public-interest prong of the balancing test under Exemptions 6 and 7(C) was an interest that complied with the central purpose doctrine. ${ }^{40}$ Department of De-

35. Id. at 175 (quoting United States Dep't of the Air Force v. Rose, 425 U.S. 352, 372 (1976)).

36. Id. at 178.

37. Id.

38. Id. at 178-79. The argument proffered by the FOIA requester has come to be called a "derivative-use" theory: The information is valuable not just for its own sake but also because it may be used to discover, or "derive," additional information. The Court asserted that in rejecting the proffered justification for releasing the names, it was not deciding the question of whether a "derivative use" of FOIA information ever could meet the public interest prong of the balancing test. Id. at 179. Instead, the Court said that in this case, the argument in favor of a derivative use of the refugees' names was "[m]ere speculation about hypothetical public benefits." Id. On the other hand, Justice Scalia suggested that despite what the Court said, the implication of the Court's ruling was that it would not accept a "derivative-use" rationale in any case: "I choose to believe the Court's explicit assertion that it is not deciding the derivative-use point, despite what seem to me contrary dicta elsewhere in the opinion." Id. at 182 (Scalia, J., concurring).

39. United States Dep't of Defense v. Federal Labor Relations Auth., 114 S. Ct. 1006 (1994).

40. Id. at 1012 ("[T]he ouly relevant 'public interest in disclosure' to be weighed in this balance is the extent to which disclosure vould serve the 'core purpose of the 
fense involved FOIA requests for the home addresses of civilian, non-union workers at stores on military bases. The requesters were the unions that represented the bargaining units at those stores, and the umons argued that having the home addresses would facilitate the nation's public policy of allowing collective bargaining for public employees. ${ }^{41}$ The Court held that the plaintiffs' derivative-use argument did not comply with the principles of FOIA's central purpose because the derivative use of the workers' home addresses to help a umion's organizing efforts would not reveal what the government has been "up to." ${ }^{\text {"42 }}$ The Court did not exphicitly reject the notion that a derivative use of FOIA infornation might serve the central purpose of the Act. The Court, however, accomphished virtually the same result when it held that a FOIA request "cannot turn on the purposes for which the request for information is made." ${ }^{, 33}$ The Court justified its rejection of the labor union's derivative-use arguments on the

FOIA' which is 'contribut[ing] significantly to public understanding of the operations or activities of the government."' (quoting Reporters Committee, 489 U.S. at 775)).

41. Id. at 1009-10.

42. Id. at 1013-14. Arguing that the case had a "virtually nonexistent FOIA-related pnblic interest," $i d$. at 1015 , the Court minced no words:

The relevant public interest supporting disclosure in this case is negligible, at best. Disclosure of the addresses mighit allow the unions to communicate more effectively with employees, but it would not appreciably further "the citizens" right to be informed about what their government is up to." . . . Indeed, such disclosure would reveal little or nothing about the employing agencies or their activities.

Id. at 1013-14 (quoting Reporters Committee, 489 U.S. at 773).

43. Id. at 1013 (quoting Reporters Committee, 489 U.S. at 771). This statement by the Court exaggerates the legal significance of the changes wrought by FOIA's 1966 enactment. See Dickinson, supra note 30, at 209-10. As the legislative history of the Act makes clear, the authors of the FOIA were particularly interested in extirpating one specific problem that the old "Public Information" section of the Administrative Procedures Act had failed to address: the practice by government officials of denying access to the information solely because of the purpose of the person's request. See H.R. REP. No. 1497 , supra note 30 , at 2422-23. Thus, the drafters demied agency officials the discretion to consider the purpose of a FOIA request as part of the process of determining whether to release a requested record. In so doing, the drafters' intention was to promote disclosure. Id. The Court, however, has diminished the right of access to government information by taking the language of the legislative history out of context. By highlighting Congress' desire that courts not consider the purpose of a FOIA request, the Court has transformed this principle from one that promotes disclosure to one that prevents it. As Glenn Dickinson has pointed out, the basic inspiration for the Act never varied: "The FOIA makes operative the public right to government information in order to ensure that public servants do indeed serve the public and not themselves. This watchdog function was perhaps the principal inspiration for the FOIA and has remained its symbolic central pillar." Dickinson, supra note 30, at 197. 
grounds that "because all FOIA requestors have an equal, and equally qualified, right to information, the fact that respondents are seeking to vindicate the policies behind the Labor Statute is irrelevant to the FOIA analysis." ${ }^{\text {"44 }}$

The Department of Defense decision clearly demonstrates, as Justice Gimsburg noted in her concurrence, that the central purpose doctrine has "changed the FOIA calculus" that previously leaned in favor of disclosure. ${ }^{45}$ Despite the fact that the "core purpose' limitation is not found in FOIA's language" the Act explicitly places the burden on the government to demonstrate that disclosure is not warranted, ${ }^{47}$ the central purpose doctrine is here to stay, thereby changing the focus of the Act. The doctrine has created the unforeseen result that the effective burden im a FOIA case has shifted to the FOIA requester and against the underlying principle of disclosure. The requester now must do more than simply ask for the inforination; he also must show that the information he seeks will reveal what his government has been "up to."

\section{B. A "Modest Proposal"48 for the Central Purpose Doctrine}

At the very time that the Court was preparing its elucidation of the central purpose doctrine in Department of Defense, a group

44. Department of Defense, 114 S. Ct. at 1014. Although the Court never has exphcitly announced its position with respect to derivative-use arguments, the U.S. Courts of Appeals for the Second, Ninth, Tenth, and District of Columbia Circuits have interpreted Department of Defense and the Court's earher decisions as precedents that place all derivative-use arguments outside the scope of FOIA's balancing test. See Sheet Metal Workers Int'l Ass'n, Local No. 9 v. United States Air Force, 63 F.3d 994, 998 (10th Cir. 1995); Painting Indus. of Hawaii Mkt. Recovery Fund v. United States Dep't of the Air Force, 26 F.3d 1479, 1485 (9th Cir. 1994); Painting \& Drywall Work Preservation Fund v. Department of Hous. \& Urban Dev., 936 F.2d 1300, 1303 (D.C. Cir. 1991); Hopkins v. United States Dep't of Hous. \& Urban Dev., 929 F.2d 81, 87-88 (2d Cir. 1991).

45. Department of Defense, $114 \mathrm{~S}$. Ct. at 1017 (Ginsburg, J., concurring in the judginent).

46. Id. at 1018 (Ginsburg, J., concurring in the judgment).

47. 5 U.S.C. $\S 552(a)(4)(B)$ (1994) ("[T]he burden is on the agency to sustain its action.").

48. Cf. Jonathan Swift, A Modest Proposal for Preventing the Children of poor People in Ireland, From Being a Burden to Their Parents or CounTRY; AND FOR MAKING THEM BENEFICIAL TO THE PUBLICK (1729), reprinted in IRISH TRACTS, 1728-1733, at 109 (Herbert Davis ed., 1955) (suggesting satirically that the solution for the problem of overpopulation of poor people in Ireland was for the English to eat Irish children). 
of commentators suggested that the doctrine should not be confined only to Exemptions 6 or $7(\mathrm{C}){ }^{49}$ They argued that the doctrine should be a filter through which all FOIA requests are judged. ${ }^{50}$ Professor Cate and his co-authors, who have represented clients on FOIA matters before administrative agencies, claimed that the justifications for the central purpose doctrine are just as viable for every other FOIA exemption as they are for Exemptions 6 and $7(\mathrm{C}) .^{51}$ The commentators argued that government agencies should apply the limitations of the individual exemptions-such as the protection for law enforcement inforination in Exemption 7(D) or for confidential business inforination in Exemption 4-only after a FOIA request survives the central purpose doctrine as a threshold test:

The test for whether a request seeks "official information" should be the touchstone for disclosure under FOIA. Rather than limit the application of a "central purpose" test to one or more of the FOIA exemptions, only information that will serve the purpose of ensuring that the Government's activities be opened to the "sharp eye of public scrutiny" should ever be subjected to disclosure under FOIA. Under this test, an agency receiving a request for documents under FOIA would determine whether it possessed any responsive documents, and if so, whether those documents shed hight "on what the Government is up to." If the agency determined that the documents did not do so, it would deny the request. ${ }^{52}$

Neither Congress nor the Court has explicitly adopted the approach advocated by Professor Cate and his colleagues. Indeed, their proposal would work a dramatic volte face from the principles of FOIA, improperly shifting the Act from one that favors disclosure to one that favors secrecy. Nevertheless, in some of the recent lower federal court decisions regarding FOIA, courts have taken the invitation offered by Professor Cate, and have applied

49. Cate et al., supra note 7 , at 67 . This article was published in the winter edition of the law review, which was released in January 1994. The Supreme Court's decision in Department of Defense was filed February 23, 1994.

50. Cate et al., supra note 7, at 67-69.

51. Id See also Amy Rees, Note, Recent Developments Regarding the Freedom of Information Act: A "Prologue to a Farce or Tragedy; Or, Perhaps Both", 44 DUKE L.J. 1183, 1217 (1995) (arguing that the "central purpose" principles of the Act should be applied to questions involving Exemptions 1 and 4).

52. Cate et al., supra note 7 , at $67-69$. 
the central purpose doctrine in areas outside the privacy exeinptions. ${ }^{53}$ These decisions suggest that the doctrine eventually will develop the dramatic scope that Professor Cate and his colleagues envision for it.

\section{The Central Purpose Doctrine at Work Today}

The principal field of battle for the central purpose doctrine remams within the privacy exemptions that gave birth to it, Exeinptions 6 and 7(C), with the most orthodox apphication of the doctrine being the prevention of disclosure. As inentioned supra, Exemption 6 allows the Government to withhold "personnel and medical files and similar files" when the disclosure "would constitute a clearly unwarranted invasion of personal privacy." ${ }^{34}$ The comparable standard under Exemption $7(\mathrm{C})$ is somewhat less demanding than under Exemption $6 ;^{55}$ the exemption is limited to "records or information compiled for law enforcenent purposes." Such records may be withheld when they "could reasonably be expected to constitute an unwarranted mvasion of personal privacy."${ }^{\text {"56 }}$

\section{A. Exemption 6 Cases}

In 1995, the U.S. Court of Appeals for the Tenth Circuit led the way in applying the full force of the central purpose doctrine in a case that was strikingly similar to Department of Defense. ${ }^{57}$ Just as in Department of Defense, the FOIA plaintiff in Sheet Metal Workers International Association, Local No. 9 v. United States Air Force was a union seeking the names of civilian workers at a military installation. ${ }^{58}$ This time, however, the request was not motivated by a desire to try to convince those workers to join the union. Instead, the union said it wanted the names of the workers einployed by the Air Force's construction contractors at

53. See cases discussed infra section II.C.

54. 5 U.S.C. $\S 552(\mathrm{~b})(6)(1994)$.

55. See United States Dep't of Defense v. Federal Labor Relations Auth., $114 \mathrm{~S}$. Ct. 1006, 1013 n.6 (1994) ("Exemption 7(C) is more protective of privacy than Exemption 6.").

56. 5 U.S.C. $\$ 552(b)(7)(C)(1994)$.

57. See Sheet Metal Workers Int'l Ass'n, Local No. 9 v. Umited States Air Force, 63 F.3d 994 (10th Cir. 1995).

58. Id. at 995. 
the Air Force Academy so that the union could ensure that the contractors-and by extension, the Air Force-were complying with the prevailing-wage requirements of the Davis-Bacon Act. ${ }^{59}$ At the administrative level and at trial, the Air Force refused to release any portion of the certified payroll records, ${ }^{60}$ but the district court's magistrate judge recommended that the payroll records be released with all "personal identifiers" redacted. ${ }^{61}$ The district court modified the magistrate judge's order to require the Air Force to release the names of the workers, but not their home addresses, social security numbers, withholding exemptions or net wages. ${ }^{62}$ On appeal, the Air Force challenged only the district court's order to release the names of the workers. ${ }^{63}$

In its decision in favor of the Air Force, the Tenth Circuit found that the public interest in support of releasing the names was "too attenuated" to overcome the privacy interests of the workers. ${ }^{64}$ The panel acknowledged the controlling autliority of the central purpose doctrine in Department of Defense and Reporters Committee, finding that the release of the workers' names would not reveal what the government was "up to." 65 Furthermore, the panel explicitly rejected the "derivative-use" theory presented by the union, which claimed that the disclosure of the names would lead to information about wliether the Air Force was complying witli the Davis-Bacon Act. ${ }^{66}$ The panel cited three earlier decisions im other circuits to support its own conclusion that despite whatever public interest might be served by suclı a derivative use of the FOIA information, this public interest was so attenuated that it did not overcome the significant privacy interests of the workers. ${ }^{67}$

59. Id. The Davis-Bacon Act, ch. 411, 46 Stat. 1494 (1931) (codified as amended at 40 U.S.C. $\$ \S 276 a$ to $276 a-5$ (1994)), requires that workers employed at federal construction projects be paid wages at the rate prevailing for similar workers in the project area. Id. at $\S 276 \mathrm{a}$.

60. Sheet Metal Workers, Local No. 9, 63 F.3d at 995-96.

61. Id. at 996.

62. Id.

63. Id.

64. Id. at 998.

65. See id. at $997-98$.

66. See id. at 998.

67. Id. Two of these earlier decisions preceded the 1994 decision in Department of Defense, and the third, from the Ninth Circuit, was decided in its wake. See Paimting Indus. of Hawaii Mkt. Recovery Fund v. Department of the Air Force, 26 F.3d 1479 (9th Cir. 1994); Painting \& Drywall Work Preservation Fund v. Department of Hous. \& Ur- 
The Sheet Metal Workers, Local No. 9 decision seems almost unremarkable in its application of the central purpose doctrine. The requested information was a small part of the billions of bytes of data stored in government computers about individuals who have only periplieral contact with the government. The payroll information was not information specifically about what the government had done-it was information about individuals. Fmally, the union intended to use the information, at least in part, to make follow-up contacts with the workers, thus imtruding on the workers' peace and quiet. All in all, the case seems to be completely in line with current applications of the central purpose doctrine.

Nevertheless, the implications of Sheet Metal Workers, Local No. 9 are starkly antithetical to the goals of FOIA: Without the names of the workers, the union will be unable to correlate the payroll information it receives. Because of this inability, neither the union nor any otlier private citizen will be able to determine whether the contractors and the Air Force are fulfilling their statutory obhigations to pay a prevailing wage. ${ }^{68}$ Thus, the promise mitially offered by FOIA, that it would einpower private watchdogs to ensure government accountability, has been rendered impotent by decisions such as Sheet Metal Workers, Local No. 9.

This exact concern motivated an opposite resolution in Sheet Metal Workers' International Ass'n Local Union No. 19 v. Department of Veterans Affairs. ${ }^{69}$ As in the earhier Tenth Circuit decision, the district court in Philadelphia was asked to resolve a request for certified payroll information concerning employees of private contractors on a federal government construction project. $^{70}$ Also, as in the earlier case, the ostensible purpose for the FOIA request was to allow the union to ensure that the contractors-and the Department of Veterans Affairs-were abiding by the prevailing wage requirements of the Davis-Bacon Act. ${ }^{71}$ How-

ban Dev., 936 F.2d 1300 (D.C. Cir. 1991); Hopkins v. Department of Hous. \& Urban Dev., 929 F.2d 81 (2d Cir. 1991).

68. The idea that the stripped-down data, without names or other identifiers, will be sufficient for the union's purposes is simply specious. The payroll information cannot be tabulated without correlating it to particular individuals. Even then, the information unust be corroborated by double-checking with the individual workers.

69. No. CIV.A.95-0935, 1995 WL 552876 (E.D. Pa. Sept. 14, 1995).

70. Id. at $* 1$.

71. Id. 
ever, unlike the Tenth Circuit, the district court did not rule that this derivative use of the FOIA information was too attenuated to justify the invasion of the workers' privacy. Instead, the court ruled that the FOIA request served a "strong" public interest, the independent assurance of compliance with the Davis-Bacon Act. ${ }^{72}$ Consequently, the court ordered the government to provide the certified payroll records. ${ }^{73}$ The court required the government to reveal the names, addresses, gross and net wages of the workers, and allowed only the redaction of the workers' social security numbers. ${ }^{74}$

The Sheet Metal Workers' Local Union No. 19 court reached this conclusion by finding that the central purpose doctrine of Reporters Committee and Department of Defense did not prevent a derivative-use justification for a FOIA request. ${ }^{75}$ Moreover, the court specifically held that those cases had not overruled an earlier Third Circuit decision ${ }^{76}$ that relied on a derivative-use theory. ${ }^{77}$ The court einphasized that the Reporters Committee and Department of Defense cases shonld be distinguished from the Third Circuit's decision because that earlier decision explicitly had recognized that "monitoring an agency's enforcement of Davis-Bacon is a 'strong' interest and 'exactly the kind of public interest Congress intended FOIA to facilitate."'78

The district court's decision, although faithful to the original aspirations of FOIA, is unlikely to command mucli appellate support. The court overlooked the language in Department of Defense that suggested the Supreme Court would disniss claims based on virtually any derivative use of FOIA information. ${ }^{79}$ The court failed to recognize that the Department of Defense decision, by focusing solely on whether the requested FOIA information directly provides information about what the government was "up to,"

72. Id. at *7.

73. Id. at $* 8$.

74. Id.

75. Id. at *6-*7.

76. International Bhd. of Elec. Workers Local Union No. 5 v. United States Dep't of Hous. \& Urban Dev., 852 F.2d 87 (3d Cir. 1988) [hereinafter $I B E W]$. The $I B E W$ decision upheld release of FOIA information that would allow a union to monitor a contractor's compliance with, and government enforcement of, the Davis-Bacon Act. Id.

77. Sheet Metal Workers' Local Union No. 19. at *7.

78. Id. (quoting $I B E W, 852 \mathrm{~F} .2 \mathrm{~d}$ at 91 ).

79. See Umited States Dep't of Defense v. Federal Labor Relations Auth., 114 S. Ct. 1006, 1013-14 (1994); see also supra notes $41-44$ and accompanying text. 
ensured defeat for almost any derivative-use argument. ${ }^{80}$ The Supreme Court's decisions on the central purpose doctrine have sounded a death knell for the very kind of argument on which the district court relied-that FOIA information should be disclosed if it eventually might lead to further information about agency action. $^{81}$

\section{B. Exemption $7(C)$ Cases}

As previously noted, the two Sheet Metal Workers cases dealt witl Exemption 6. However, most of the recent cases mvoking the central purpose doctrine involve Exemption $7(\mathrm{C})$, the privacy exemption for law enforcement records. ${ }^{82}$ The analytical paradigm of the Exemption 7(C) cases is best illustrated by a Third Circuit decision involving the former "consighiere" ${ }^{83}$ of the New Jersey faction of the Genovese organized crime family. ${ }^{84}$ In Manna $v$. United States Department of Justice, the panel majority held that the plaintiff's asserted public interest in obtaining law enforcement documents relating to his prosecution and conviction for inurder was at best a hypothetical interest, and certainly not one that would outweigh the privacy interests of the law enforceinent officers, witmesses, and interviewees who were identified in the documents. ${ }^{85}$ Mr. Manna claimed that the disclosure of the documents would serve the "public's interest in the administration of criminal justice and assure that the innocent are not wrongfully convicted and confined" by uncovering government wrongdoing in the form of illegal electromic surveillance, electronic mampulation of intercepted conversations, and failure to turn over exculpatory material. $^{86}$ The panel majority, however, accepted the trial court's find-

80. See Department of Defense, 114 S. Ct. at 1014.

81. Cf. United States Dep't of State v. Ray, 502 U.S. 164, 179 (1991) ("Mere speculation about hypothetical public benefits cannot outweigh a demonstrably significant invasion of privacy.").

82. According to a search of the Westlaw ALLFEDS database, of the twenty-four FOIA cases in 1995 that relied on the central purpose doctrine, sixteen dealt with rulings on the scope of Exemption 7(C).

83. In the context of the American mafia, a "consighiere"-an Italian word for "counsellor" or "advisor"-is someone with significant authority in the organization. $C f$. MARIO PUZO, THE GODFATHER (1969).

84. See Manna v. Umited States Dep't of Justice, 51 F.3d 1158 (3d Cir.), cert. denied, 116 S. Ct. 477 (1995) [leremafter Manna II].

85. See id. at 1166.

86. See id. 
ing that the only interest truly at stake in this FOIA request was Mr. Manna's personal interest in attempting to win his freedoin in a habeas corpus petition. ${ }^{87}$

At the trial level, the district court had ruled that such a private interest would not serve the purpose of FOIA, as identified in Reporters Committee, of shedding the hight of public scrutiny on agency actions. ${ }^{88}$ The panel majority agreed; it found that Mr. Manna's allegations of government misconduct were unfounded and hypothetical. ${ }^{89}$ The panel said Mr. Manna first inust prove his allegations of misconduct before he could have access to the government documents. ${ }^{90}$

Of course, this requirement by the Third Circuit of mitially proving government misconduct presents a Catch-22 conundrum for the plaintiff: If the documents he seeks will show government misconduct, how can he offer the "proof" of misconduct without first gaining access to the documents? Circuit Judge Edward R. Becker avoided this conundrum in his dissenting opinion by focusing on the strength of Mr. Manna's claim that there was governInent misconduct in the prosecution. ${ }^{91}$ The dissent pointed out that the documents already released to Mr. Manna showed more than a distinct possibility that the goverument began its wiretap on Mr. Manna's phone before the wiretap was authorized formally by court order. ${ }^{92}$ This discrepancy demonstrated that Mr. Manna's allegations of government misconduct may be "a viable legal theory." With such a legal theory, Judge Becker said, Mr. Manna ought to ineet the test of the central purpose doctrine: "As a rule, the public's interest in exposing government corruption and wrongdoing is the primary rationale for FOIA. . . . Given the discrepancy in the dates [for the wiretap information], it seems to me that

87. See id.; see also Manna v. United States Dep't of Justice, 815 F. Supp. 798, 809 (D.N.J. 1993), affd, 51 F.3d 1158 (3d Cir.), cert. denied, 116 S. Ct. 477 (1995) [hereinafter Manna $I$ ] ("Plaintiff has only asserted his own personal interest in having his illegal conviction' overturned.").

88. See Manna 1, 815 F. Supp. at 809.

89. See Manna $I I, 51$ F.3d at 1166.

90. Id. ("Absent proof of miscouduct, which is needed to justify invading the demonstrable privacy interests involved here, we 'need not linger over the balance' because 'something . . . outweighs nothing every time." (quoting National Ass'n of Retired Fed. Employees v. Horner, 879 F.2d 873, 879 (D.C. Cir. 1989))).

91. Id. at 1169 n.3 (Becker, J., dissenting).

92. Id.

93. Id. 
the district court should not have concluded ... that no pubhic interest was implicated by Manna's request." 94

Despite the routime nature of the panel majority's treatment of the central purpose doctrine in Manna, ${ }^{95}$ the case is especially noteworthy for another feature. Both the district court and the panel majority considered the identity of the requester in determining that his request should be denied. ${ }^{96}$ This feature of the decision violates the general rule that the identity of a FOIA requester, or low lie will use the requested information after it is released, is irrelevant to the resolution of a FOIA request. ${ }^{97}$ The Third Circuit, however, reasoned that this was an exceptional case. Mr. Manna was not the same as other FOIA requesters, and because of his continuing colmection with the "sordid and bloody" Genovese organized crime family, Mr. Manna's FOIA request sliould be treated differently. ${ }^{98}$ The court adopted the findings of the district court that the disclosure of the requested documents would make the people who assisted in the prosecution of $\mathrm{Mr}$. Marma "unnecessarily vulnerable to possible harassinent and retaliation." Thus, according to the panel nrajority, "[a]lthough a court does not usually take a requester's identity into consideration, Manna's position in the hierarchy of a particularly influential and violent $\mathrm{La}$ Cosa Nostra family is highly nuaterial to the protection of individual privacy...."100 On the other hand, Judge Becker's dissent ponited out that the court's concern about retaliation against people identified in the requested documents is not a cognizable interest under the public interest/private interest balancing test of Exemption 7(C): "While I agree that this infornation

94. Id.

95. The majority disposed of the Exemption 7(C) question in five paragraphs. See id. at 1166.

96. See id:; Manna I, 815 F. Supp. at 809-10.

97. The Supreme Court has said that "all FOIA requestors have an equal, and equally qualified, right to information." Umited States Dep't of Defense v. Federal Labor Relations Auth., 114 S. Ct. 1006, 1014 (1994). The rule that a requester's identity is irrelevant to the consideration of his request derives from Congress's intent in the original 1966 Act to inake government information more accessible. See H.R. REP. No. 1497, supra note 30 , at 2426 (declaring that pubhic records shall be available to "any person," rather than the previous rule that government information was available only to "persons properly and directly concerned" with the inaterial); see also discussion of the legislative history of FOIA, supra note 43.

98. See Manna II, 51 F.3d at 1165, 1166.

99. Id. at 1166 (quoting Manna I, 815 F. Supp. at 810).

100. Id. 
[concerning Mr. Manna's background] is relevant under Exemption 7(F), I disagree with the government that the threat of retaliation is a cognizable concern under Exemption 7(C). Retaliation has nothing to do with privacy ...."

The court's ruling suggests that the Third Circuit las expanded the scope of Exemption 7(C). Under the court's interpretation, the privacy interests protected by the exemption extend to more than simply the direct results of disclosing the documents. The privacy interests also mclude avoiding the indirect results-the secondary effects-that might flow from disclosing the documents. ${ }^{102}$ These secondary effects include the potential for retaliation against witnesses who provided evidence against Mr. Manna. Any sort of retaliation against these witnesses is a kind of derivative use of the information. Thus, the court's use of Mr. Manna's identity as a rationale for withholding disclosure suggests that a kind of negative derivative-use analysis is appropriate on the privacy side of the balancing test. This application of a derivative-use rationale stands in stark contrast to its more common use as an argument in favor of disclosure, a use that courts liave not favored. ${ }^{103}$ In the context of law enforcement records, this expansion of the scope of the privacy interest makes sense, especially in light of the ever-present concern for protecting witnesses from retaliation. It is a very slort step, however, to apply this expanded notion of the privacy interest to the Exemption 6 context, where there is no concern for witness retaliation. Indeed, the Supreme Court has suggested that the scope of the privacy interests under both Exemption 6 and $7(C)$ mcludes the secondary effects of disclosing governunent information. ${ }^{104}$

The D.C. District Court employed a similarly expansive interpretation of privacy interests in another notewortlyy Exemption 7(C) case. ${ }^{105}$ In Exner v. United States Department of Justice, the alleged former mistress of President Kennedy sought information

101. Id. at 1170 (Becker, J., dissenting).

102. See id. at 1166.

103. See, e.g., United States Dep't of State v. Ray, 502 U.S. 164, 182 (1991) (Scalia, J., concurring).

104. Id. at 171-79 (1991) (expressing concern for potential secondary effects that might arise from contacting Haitian returnees in Haiti); United States Dep't of Defense v. Federal Labor Relations Auth., 114 S. Ct. 1006, 1013-16 (1994) (ruling that disclosing workers' hone addresses was unwarranted in part because unions would use the information to contact workers at lonie).

105. See Exner v. United States Dep't of Justice, 902 F. Supp. 240 (D.D.C. 1995). 
concerning a 1962 break-in at her apartment. ${ }^{106}$ Miss Exner already had obtamed documents froin the FBI recounting how the Bureau had staked out her apartment because of concerns that her relationships with organized crime figures would compromise the President. ${ }^{107}$ She filed suit under FOIA to force the FBI to reveal the names of people imphicated in the break-in at her apartment. ${ }^{108}$ Documents showed that during the course of their stakeout, FBI agents observed two inen breaking into Miss Exner's apartment, and one of the men appeared to be the son of a former FBI agent. ${ }^{109}$

In response to Miss Exner's imitial FOIA request, the Bureau redacted the names of both the former agent and his two sons from the copies of the documents that Miss Exner received. ${ }^{110}$ She challenged the redactions on grounds that an invasion of privacy was warranted because disclosure of the names of the people involved would help the public understand whether the FBI had been involved in mappropriate spying on her or in a cover-up to protect the former agent and his family. ${ }^{111}$ The district court, however, ruled that this asserted public interest was "minimal at best"112 in large part because Miss Exner had failed to deinonstrate any "nexus between the break-in to her apartment and the FBI, save for the fact that the FBI observed the break-in."113 The court found that the information sought by Miss Exner-the names of the former FBI agent and his sons-would not shed any more light on the FBI's activities than the illumination already provided by the redacted documents. ${ }^{114}$

This ruling implicitly rejects the notion that derivative uses of requested information may be weighed on the public interest side of the Exemption 7(C) balancing test because they will shed light on agency action. For example, with the names of the agent and his sons, Miss Exner may be able to determine whetler the FBI pursued any prosecution against the person seen breaking into her

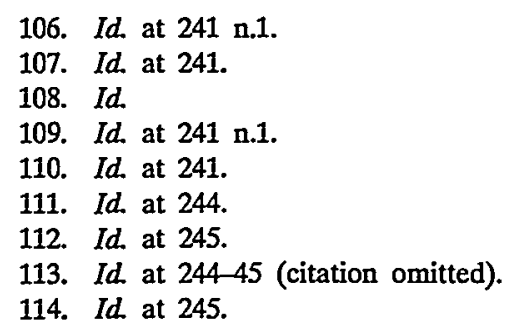


apartment. She may be able to determine whether the FBI showed any favoritism to such a suspect because of his familial connection to the Bureau. Such information obviously would reveal what a government agency has been "up to." Nevertheless, for the court, this derivative use of the FOIA information was not cognizable because the disclosure of information directly relating to agency action-the central purpose doctrine-"is the "only public interest relevant for purposes of Exemption 7(C)."'115

Against this "minimal at best" pubhic interest, the court evaluated the privacy interest as very great indeed. ${ }^{116}$ In so doing, the court included the very kind of derivative uses of the requested information that it had failed to incorporate in its consideration of the public interest. The court found that although the former FBI agent and his son were not targets of an investigation, were neither witnesses nor interviewees, and were not even the agents involved in the investigation,

disclosure of a person's name under these circumstances could be viewed as constituting an even greater invasion of personal privacy than it would for a person who was actually the subject of an investigation, because of the speculation that would attend disclosure of the names under the circumstances presented here. ${ }^{117}$

Thus, for the court's purposes, part of the privacy interest to be protected in the Exemption 7(C) balancing test is the interest in avoiding speculation by third parties that might accompany the disclosure of the names of the FBI agent and his sons.

The court's resolution of Miss Exner's FOIA claim appears to be wholly in line with the recent elaborations of the central purpose doctrine, and especially with the doctrime's inevitable tendency to overvalue privacy interests and diminish interests in disclosure. Rather than being incorrect, the court's decision simply reflects the perversity of the central purpose doctrime carried to its usual conclusion. The doctrime ostensibly focuses on ensuring that FOIA is a viable tool for government watchdogs, but it renders these watchdogs toothless in the face of a privacy claim. When a privacy claim is raised-no matter how attenuated or out-ofdate $^{118}$ - the FOIA requester must show that the information she

115. Id. at 244 (quoting Davis v. United States Dep’t of Justice, 968 F.2d 1276, 1282 (D.C. Cir. 1992)).

116. Id. at $243-44$.

117. Id. at 244.

118. Miss Exner's FOIA complaint was filed 30 years after the events in question, 
seeks will disclose agency action in the first instance. The FOIA information cannot be used to lead indirectly to other informatiou that will reveal the details of agency action. It must be related directly to what the agency is "up to," or it will remain secret.

\section{The Doctrine Expands Beyond Privacy Exemptions}

The decisions in Exner, Manna, and the two Sheet Metal Workers cases all addressed the central purpose doctrine within the conventional context of Exemptions 6 \& 7(C). In 1995, however, several courts signaled a broadening of the scope of the central purpose doctrine by incorporating its terns into the analysis of cases that had little to do with these traditional privacy exemptions.

1. The Sweetland Case. The most uoteworthy of these cases is the D.C. Circuit's per curiam ruling that the Executive Residence staff of the White House is not an "agency" under FOIA. ${ }^{119}$ In Sweetland $v$. Walters, the court upheld demial of a FOIA request filed by the lawyer representing a forner White House assistant clief who was iuvolved in an employment discrimination suit against the Executive Residence. ${ }^{120}$ The court's initial grounds for its decisiou cited the line of cases that dealt witl whether agencies of the Executive Office of the President were subject to FOIA. ${ }^{121}$ The court said these cases were relevant, even thougli the Executive Residence staff was not part of the Executive Office, because the Executive Residence staff is responsible directly to the President and performs whatever duties the President prescribes. ${ }^{122}$ The Executive Residence staff lacked the "substantial independent authority to direct executive branch officials" that is essential for a White House entity to be

and the former FBI agent in question was dead at that point. His sons, however, were still living. See id. at 243,243 n.5.

119. See Sweetland v. Walters, 60 F.3d 852 (D.C. Cir. 1995) (per curiam).

120. Id. at 853. The assistant chef was one of 36 domestic employees and 33 tradespeople who make up the Executive Residence staff. See id. at 854 (quoting S. REP. No. 286, 103d Cong. 2d Sess. 51 (1994)).

121. Id. at 854 (citing Meyer v. Bush, 981 F.2d 1288 (D.C. Cir. 1993); Pacific Legal Found. v. Council on Envtl. Quality, 636 F.2d 1259 (D.C. Cir. 1980); Soucie v. David, 448 F.2d 1067 (D.C. Cir. 1971)).

122. Sweetland, 60 F.3d at 854 . 
considered an "agency" for FOIA purposes. ${ }^{123}$ The Executive Residence staff could not be considered an agency for FOIA purposes because "neither Congress nor the President has delegated independent authority to these employees." 124

This first part of the court's decision is relatively straightforward. In the second half of the opinion, however, the court invokes the principles of the central purpose doctrine to rebuff an argument by the appellant that the court's decision will frustrate the policy objectives of FOIA. ${ }^{125}$ The court argues that its decision to exclude the Executive Residence staff from the definition of an agency for FOIA purposes will not violate the central purposes of the Act because:

FOIA was intended to enlighten citizens as to how they are governed.... Absent explicit instructions to the contrary, we will not presume that Congress intended to impose on members of the President's personal staff so unseemly a duty as revealing the intimate details of the management of his home, particularly when those details will often be closely connected to his duties as head of State as well as head of Government. ${ }^{125}$

The court's language im this case, thus, represents an innovative application of the central purpose doctrine. In Sweetland, the D.C. Circuit presented the central purpose doctrine as an alternative ground for deciding a case that has nothing to do with a privacy exemption. The doctrine was used as a filter through which to view a FOIA request. The court appears to have decided that it need not apply any of FOIA's exeinptions, including the privacy exemptions, because the requested imformation will not serve the basic purposes of the Act. ${ }^{127}$ Thus, Sweetland stands for at least the proposition that when determining whether a particular government agency is an "agency" for FOIA purposes, the central purpose doctrine will be a relevant, if not dispositive, consideration. ${ }^{128}$

123. Id. (quoting Meyer, $981 \mathrm{~F} .2 \mathrm{~d}$ at 1297).

124. Id.

125. Id at 855 .

126. Id. (citing United States Dep't of Justice v. Reporters Comm. for Freedom of the Press, 489 U.S. 749, 775 (1989)).

127. See id.

128. The court's application of the central purpose doctrine picks up on an intiniation of a similar view in an earlier D.C. District Court case dealing with the agency status of the Smithsonian Institution. Dong v. Smithsonian Institution, 878 F. Supp. 244 (D.D.C. 1995) (holding that the Smithsonian is an "agency" for FOIA purposes because of its ex- 
2. The Baizer Case. Another unusual application of the central purpose doctrine arose in a case involving a FOIA request by an Oakland, California attorney for an electronic copy of the Air Force's computerized database of Supreme Court opinions, known as "JURIS." 129 In Baizer v. United States Department of the Air Force, the court found that the database sliould not be considered an "agency record" within the scope of FOIA. ${ }^{130}$ The court said the legal database ${ }^{131}$ was maintained by the government "for reference purposes only," and it was not incorporated in the Air Force's decisionmaking process. ${ }^{132}$

In a later portion of the opinion, the court considered the applicability of FOIA's central purpose; this analysis arose in the course of discussing an earlier Nintl Circuit precedent that had intimated an early version of the central purpose doctrine. ${ }^{133}$ In Baizer, the court said the earlier FOIA request in SDC Development Corp. v. Mathews-for a medical researcl database-was indistinguishable from the FOIA request in Baizer. ${ }^{134}$ As the Baizer court pointed out, the Ninth Circuit's holding in $S D C D e$ velopment relied on an understanding of the purposes of FOIA that later would crystallize into the central purpose doctrine in Reporters Committee. ${ }^{135}$ Following the reasoning in SDC Develop-

tensive federal involveinent and independent decisionmaking authority). In Dong, the district court made an oblique-but telling-reference to the central purpose of FOIA when it discnssed the legislative history of the Act: "This focus on governmental involvement im FOIA's definition of 'agency' is designed ... to protect 'the right of the individual to be able to find out how his [or her] government is operating." Id at 246 (citing H.R. REP. No. 1497 , supra note 30 , at 2423 ). No similar reference to the ceutral purpose of FOIA was included in the other 1995 case dealing with FOIA's definition of an agency. Armstrong v. Executive Office of the Presideut, 877 F. Supp. 690 (D.D.C. 1995) (holding that the National Security Council is an "agency" for FOIA purposes when it does not act solely to advise the President).

129. Baizer v. United States Dep't of the Air Force, 887 F. Supp. 225, 226 (N.D. Cal. 1995).

130. Id.

131. The Air Force had created the database through data transfers from other federal agencies and private publishers. The database thus represented a compilation of information froin several sources, rather a single source. Id. at 228-29.

132. Id. at 227.

133. See id. at 228 (citing SDC Dev. Corp. v. Mathews, 542 F.2d 1116, 1119 (9th Cir. 1976)).

134. See id. at 227.

135. See id. at 228 (quoting United States Dep't of Justice v. Reporters Comm. for Freedoin of the Press, 489 U.S. 749, 773 (1989)). 
ment, the Baizer court concluded that because the Air Force's computer database would not reveal what an agency was "up to," the database should not be regarded as an "agency record" withm the scope of FOIA. ${ }^{136}$

The decision in Baizer illustrates that yet another category of applications is available for the central purpose doctrine. Baizer teaches that the principles of the central purpose doctrine are relevant when determining whether certain documents or records ought to come within the definition of an "agency record" for FOIA purposes. The outcome in Baizer may seem generally acceptable: The Air Force's JURIS database essentially duplicates information that is available at many public libraries and denymg access to the Air Force's database does not mean the information is unobtainable. The court reaches this outcome, however, by a means that ensures the public will have little access to other kinds of government databases that are not so easily available from other public sources. The Baizer court did not address the potential rationale that the JURIS information was available elsewhere. Instead, the court used the central purpose doctrine in a way that undercuts the essential philosophy of FOIA-that public access to government information should be as broad as possible.

3. The Vazquez-Gonzalez Case. The central purpose doctrine found another new apphication in the resolution of a FOIA claim for attorney's fees in Vazquez-Gonzalez v. Shalala. ${ }^{137}$ In that case, a Puerto Rican pliysician initially tried by telephone to get information about Medicare billing practices from the local Medicare processing agency. ${ }^{138}$ Frustrated by delays, Dr. Vazquez-Gonzalez sent a written FOIA request on July 12, 1994, and a montll later, he filed a FOIA action in district court. ${ }^{139}$ Four months after the first information requests, the Department of Healtll and Human Resources provided copies of the documents that Dr. Vazquez-Gonzalez had requested at the saine time the Department moved to disıniss the FOIA suit. ${ }^{140}$

136. See id. at 228-29.

137. No. CIV.94-2100 (SEC), 1995 WL 67659 (D.P.R. Feb. 13, 1995).

138. Id. at $* 2$.

139. Id.

140. Id. 
The court found that the government had complied witl the FOIA request by providing the documents, thus rendering the civil suit moot. ${ }^{141}$ Dr. Vazquez-Gonzalez's petition for attorney's fees, lowever, survived the pendency of the merits of the suit. On that petition, the court ruled that Dr. Vazquez-Gonzalez was not entitled to attorney's fees because "he should have given defendant more time to gather the written materials, or at least called or written to inquire [about] the status of his request."142 The failure to eitler wait or inquire rendered the civil suit "unnecessary, if not frivolous." 143

The court's decision overlooks the central role that FOIA's time limits play in furthering the pohicy objectives of the Act. ${ }^{144}$ The court made no finding that the Medicare processing agency had responded to Dr. Vazquez-Gonzalez within the mandatory ten-day period, or that the agency had asked for an extension. Even more important than tliese procedural irregularities, however, is the court's alternative rationale for denying the petition for attorney's fees. Even if Dr. Vazquez-Gonzalez's FOIA suit had been necessary and non-frivolous, "the Court [found] that the suit did not advance the policy considerations of the FOIA, primarily because the information sought related to plaintiff's commercial interests $\mathrm{m}$ the pursuit of his profession." ${ }^{145}$ The court found that the information sought by Dr. Vazquez-Gonzalez did not "advance the public interest, but merely ... albeit perhaps greatly, [did advance] plaintiff plrysician's bottoin line."146 Thus, the court implied that in exercising its judicial discretion whether to award attorney's fees, it will consider the purpose of the requester in seeking the FOIA information. If a court finds that a requester's

141. Id. at $* 1$.

142. Id. at *2.

143. Id.

144. See 5 U.S.C. $\S \S 552(a)(6)(A)$-(B) (1994) (requiring an agency response to a FOIA request within ten days and an agency determination of the FOIA request within twenty days, unless entitled to an extension for "unusual circumstances"); see also H.R. REP. No. 876, supra note 12, at 6271 ("Information is often useful only if it is timely. Thus, excessive delay by the agency in its response is often tantamount to denial. It is the intent of this bill that the affected agencies be required to respond to inquiries and administrative appeals within specific time limits.").

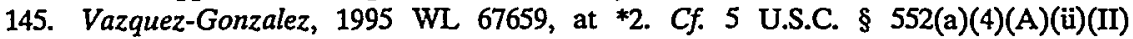
(nnaking such policy considerations relevant for the determination of fee waivers prior to any court action).

146. Vazquez-Gonzalez, 1995 WL 67659, at *2. 
purpose does not conform to the policy considerations of FOIA, then the requester should not receive attorney's fees. ${ }^{147}$

The court found support for its ruling in the joint Conference Report that accompanied the 1974 amendments to FOIA. ${ }^{148}$ This report noted that the final version of the 1974 anendinents provided for attorney's fees to FOIA plaintiffs who luad "substantially prevailed." 149 The report also noted that the final bill omitted the Senate's proposed criteria for awarding attorney's fees, which involved weighing the public benefit against the commercial benefit of the information. ${ }^{150}$ The Vazquez-Gonzalez court claimed that despite this omission of the Senate's criteria in the final bill, the conference report "suggests" to courts that they should consider the Senate's criteria when they determine whether to award attorney's fees. ${ }^{151}$

However, in its ruslı to cast Dr. Vazquez-Gonzalez's suit as a crass attempt to miprove his commercial bottoin line, ${ }^{152}$ the court undervalued the public benefit that would be derived froin the requested information. Indeed, Dr. Vazquez-Gonzalez's inedical

147. But see Jones v. Occupational Safety \& Health Admin., No. 94-3225-CV-S-4, 1995 WL 435320 (W.D. Mo. June 6, 1995) (awarding attorney's fees after finding that there had been "a prolonged non-disclosure of non-exempt documents and there was little good faith expressed on the part of OSHA"). In awarding attorney's fces in Jones, the court made no mention of the central purpose doctrine and did not consider whether the particular FOIA request advanced a public interest. Instead, the court found that OSHA should be required to pay the attorney's fees because the agency had forced the plaintiffs to go to court to get information that never should have been withheld. Id.

148. Vazquez-Gonzalez, 1995 WL 67659 at *1 n.1 (citing S. CONF. REP. No. 1200, 93d Cong., 2d Sess. 9-10, reprinted in 1974 U.S.C.C.A.N. 6285, 6288).

149. See S. CONF. REP. No. 1200 , at 6288.

150. Id.

151. See Vazquez-Gonzalez, 1995 WL 67659 , at $* 1$ n.1 (citing S. CONF. REP. No. 1200 , supra note 148 , at 6288 ).

The court, however, overstated the expressed congressional intent in claining that the Conference Report "suggests" the use of the Senate criteria. Instead, a fair reading of the Conference Report shows that the House and Senate conferees only intended not to foreclose courts from using the Senate's criteria. The conferees never said, or implied, in their report that they were "suggesting" that courts ought to use the criteria. See S. CONF. ReP. No. 1200 , supra note 149 , at 6288 .

The more appropriate source of authority for the balancing test in Vazquez-Gonzalez comes from the various Court of Appeals decisions that have announced the kind of public benefit/private benefit balancing test for attorney's fees that the court undertakes. See, e.g., Chesapeake Bay Found., Inc. v. United States Dep't of Agriculture, 11 F.3d 211, 216 (D.C. Cir. 1993), cert. denied, 115 S. Ct. 315 (1994); Aviation Data Serv. v. FAA, 687 F.2d 1319, 1321 (10th Cir. 1982).

152. See Vazquez-Gonzalez, 1995 WL 67659 , at $* 2$. 
services to patients on Medicare likely would be enhanced, if not expanded, if the doctor could ascertain the precise billing and pricing parameters imposed by the government. Thus, with more information about how the government program operates, Dr. Vazquez-Gonzalez could be more likely to provide the services that the program is intended to deliver to the public. By delaying the disclosure of the requested information, the Medicare processing agency necessarily added more uncertainty to Dr. VazquezGonzalez's medical practice.

The court's decision construed the central purpose doctrine as a rationale for narrowing the number of persons for whom attorney's fees are available when the release of government information has been wrongly delayed. This use of the central purpose doctrime goes beyond the text of the Act, ${ }^{153}$ and is ironic in light of the history of the provision for attorney's fees: Congress imserted the provisions establishing time limits and attorney's fees because it recognized that "excessive delay by the agency in its response [to a FOIA request] is often tantamount to denial."154 Congress intended to create a private incentive system to enforce FOIA much as it had done with the earlier civil rights acts. ${ }^{155}$ The Vasquez-Gonzalez court's decision, on the other hand, apphes the central purpose doctrine as a means of subverting the congressional intention to create private enforcers of FOIA's requirenients.

In Vazquez-Gonzalez, and indeed in all of the cases discussed so far, a central irony is evident in the central purpose doctrine. The doctrine functions not as a means to access government infornuation, but rather as a way to prevent access. The essential opera-

153. Cf. 5 U.S.C. $\& 552(\mathrm{a})(4)(\mathrm{A})(\mathrm{iii})$ (1994) (allowing an agency to consider the purpose of a FOIA request, but only in the context of a waiver of fees for processing and copying costs). This statutory language does not reappear in the section dealing with attorney's fees. See $\S 552(a)(4)(E)$. Moreover, the public policy interests supporting a fee waiver are significantly different from the policy considerations supporting an award of attorney's fees. Fee waivers are designed to promote access to government information by groups and individuals who otherwise would be unable to pay the fees for FOIA records. See $\$ 552(a)(4)(A)(i i i)$. On the other hand, awards of attorney's fees are designed to ensure adequate enforcement of FOIA when the government itself fails to comply with the statute. See $\$ 552(a)(4)(E)$.

154. H.R. REP. No. 876, supra note 12 , at 6271 .

155. See id. at 6272, 6272 n.10 (citing Civil Rights Act of $1964 \$ \S 201-207,701-716$, 42 U.S.C. $\$ \S 2000 \mathrm{a}$ to $2000 \mathrm{a}-6,2000 \mathrm{e}$ to 2000e-15 (1988) and Emergency Sclsool Aid Act $\S \S 701-720$, U.S.C. $\S \S 1232 a, 1601-19$, repealed by Act of Nov. 1, 1978, Pub. L. No. 95-561, tit. VI \& 601(b)(2), 92 Stat. 2268). 
tion of the central purpose doctrine reestablishes a presuinption in favor of nondisclosure, contrary to the original spirit of FOIA.

\section{The Central Purpose Doctrine as a Tool for DISCLOSURE}

Despite the almost uniform application of the central purpose doctrine as a tool to prevent disclosure, a few courts have seen the doctrine as providing the basis to require disclosure. These cases argue that when government information might indirectly lead to insights about how government operates, the public interest in disclosure under the central purpose doctrine outweighs the privacy interest in confidentiahty. However, because these rare cases rely on a derivative-use theory to justify the disclosure of law enforcement records, they are unlikely to herald any changes in the central purpose doctrine. ${ }^{156}$

\section{A. The Rosenfeld Case}

In Rosenfeld v. United States Department of Justice, ${ }^{157}$ the Ninth Circuit adjudicated a series of FOIA requests by a journalist who was looking into the FBI's investigation of the Free Speech Movement in Berkeley. ${ }^{158}$ In response to Mr. Rosenfeld's re-

156. As noted previously, the Supreme Court has not declared an explicit ruling with respect to the cognizability of derivative-use arguments in FOIA cases; however, four circuits have ruled that the derivative-use theory has no place in the FOIA balancing test. See supra note 44.

157. 57 F.3d 803 (9th Cir. 1995), cert. dismissed, 116 S. Ct. 833 (1996). This decision is the latest installment in a decade-long legal struggle that began when Mr. Rosenfeld filed his first FOIA requests in 1981 as a reporter with the Daily Californian at the University of California, at Berkeley; he filed his FOIA suit in 1985 after joining the staff of the San Francisco Examiner. See FBI Loses I5-year-old Berkeley 'Free Speech' Case, NEwS MEDIA \& L., Summer 1995, at 45, 45-46 [hereinafter FBI Loses].

The decision also is noteworthy because the reactions it subsequently sparked highlight the adversarial relationship between the unedia and the federal officials responsible for FOIA policy. The unedia applauded the decision as eminently correct; the government vehemently denounced it. Compare FBI Loses, supra, at 45-46 (reporting favorably on the decision) and Eric Brazil, FBI Tried to get UC's Chief Fired, Court Says; Agency Files on '60s Political Meddling Ordered Opened, SAN FRANCISCO EXAMINER, June 13, 1995, at A1 (reporting favorably on the decision) with OFFICE OF INFORMATION AND PRVACY, U.S. DEP'T OF JUSTICE, ROSENFELD DECISION ISSUED BY NINTH CIRCUIT, FOIA UPDATE, Spring/Summer 1995 at 13 (criticizing the decision as "conflict[ing] with the law of nearly every other circuit" and as "essentially den[ying] protection outright for numerous sources and third parties").

158. See FBI Loses, supra note 157 , at $45-46$. 
quests, the FBI located 8,432 documents, releasing some in their entirety, withholding others completely, and redacting portions of the vast majority of the documents. ${ }^{159} \mathrm{Mr}$. Rosenfeld filed suit to challenge the withholdings, and the district court agreed that inost of the documents were withheld improperly, largely because many of the documents were not compiled for legitimate law enforcement purposes. ${ }^{160}$ Instead, the district court found that most of the documents were compiled in an unlawful campaign of intimidation against the Free Speech Movement. ${ }^{161}$

The Ninth Circuit not only affirmed these findings, but it also drew on the central purpose doctrine to justify its decision to force the FBI to reveal the documents:

The sole cognizable public interest for FOIA is the interest "to open agency action to the liglt of public scrutiny," to inform the citizenry "about what their government is up to." We agree with the district court that this interest exists liere. It certainly serves FOIA's purpose to disclose publicly records that document whether the FBI abused its law enforcement mandate by overzealously investigating a political protest movennent to which some meinbers of the government then inay liave objected. ${ }^{162}$

The court also rejected the government's argument that the names of the individuals in the documents should be protected. ${ }^{163}$ The court held the Supreme Court's 1991 ruling in Ray, dealing with the names of Haitian returnees, was not applicable to this case because "the public interest in this case may not be served without disclosing the names of the investigation subjects." 164 Finally, the court appeared to endorse the applicability of a derivative-use theory for justifying the release of the requested information: "Disclosing the names of the investigation subjects would make it possible to compare the FBI's investigations to a roster of the

159. Rosenfeld, 57 F.3d at 806.

160. Id. (citing Rosenfeld v. United States Dep't of Justice, 761 F. Supp. 1440, 1448-49 (N.D. Cal. 1991)).

161. See Rosenfeld v. United States Dep't of Justice, 761 F. Supp. 1440, 1448-49 (N.D. Cal. 1991), affd in part, rev'd in part, 57 F.3d 803 (9th Cir. 1995), cert. dismissed, 116 S. Ct. 833 (1996).

162. Rosenfeld, 57 F.3d at 811-12 (quoting United States Dep't of Justice v. Reporters Comm. for Freedom of the Press, 489 U.S. 749, 772, 773 (1989)) (citations omitted).

163. Id. at 812 .

164. Id. at 812 (distinguishing United States Dep't of State v. Ray, 502 U.S. 164, 177-79 (1991)). 
[Free Speech Moveinent's] leadership. Therefore, disclosing the names of investigation subjects promotes the public interest of this FOIA request." 165

\section{B. The Detroit Free Press Case}

The Sixth Circuit developed a similar application of the central purpose doctrine in its decision by a divided panel to require the United States Marshals Service to release the mug shots of eight people under indictment and awaiting trial in Detroit. ${ }^{166}$ In Detroit Free Press, the Marshals Service liad refused to release copies of the inug shots on the grounds that the public disclosure of the pictures would cause an unwarranted invasion of the defendants' privacy under Exemption $7(\mathrm{C}) .{ }^{167}$ The court, however, ruled that disclosing the pictures would result in no invasion of privacy whatsoever, and certainly no 'unwarranted' invasion of privacy. ${ }^{168}$ The court said the indicted defendants, whose "visages had already been revealed during prior judicial appearances,"169 had no privacy interests at stake. ${ }^{170}$ Even if a privacy interest might be at stake, that concern cannot extend to avoiding "ridicule or embarrassment from the disclosure of information in the possession of government agencies."171

The Sixth Circuit argued that its determination to disclose the inug shots was bolstered by the strong public interest that would be served by niaking the pictures available to the public. In inaking this argument, the court rehed on the central purpose doctrime and a derivative-use rationale:

Public disclosure of mug shots in limited circumstances can, however, serve to subject the governinent to public oversight. For exainple, release of a photograph of a defendant can more clearly reveal the government's glaring error in detaining the wrong

165. Id.

166. See Detroit Free Press, Inc. v. Department of Justice, 73 F.3d 93 (6th Cir. 1996).

167. Id. at 95.

168. Id. at 98.

169. Id. at 97.

170. Id. ("Under these detailed circumstances, we believe that no privacy rights are implicated."). But see id. at 99-100 (Norris, J., dissenting) ("[T]he subject of a mug shot has a cognizable privacy interest in preventing its public dissemination. ... [And,] the disclosure of these mug slots would serve no public interest cognizable under the FOIA.").

171. Id. at 97. 
person for an offense than can any reprint of only the name of an arrestee. Furthermore, mug shots can startlingly reveal the circumstances surrounding an arrest and initial incarceration of an individual in a way that written information cannot. ${ }^{172}$

By saying that the disclosure of mug shots will expose the government to public oversight, the court is referring to more than merely the direct effects of publishing the pictures. Such a disclosure, in its own riglit, will not reveal what the government has been up to.' The oversight function can occur only as a derivative use of the pictures. Thus, without ever characterizing the issue as a question of the derivative use of the FOIA information, the Sixth Circuit's decision hinges on a notion that FOIA ensures citizens' access to information that will indirectly lead to conclusions about what the government is 'up to.' However, as previously discussed, most other courts have been opposed, if not hostile, to applying a derivative-use rationale as a justification for disclosure. ${ }^{173}$

The Rosenfeld and Detroit Free Press decisions represent a fundamentally different application of the central purpose doctrine. These courts have tried to transform the doctrine into one that favors disclosure rather than secrecy, the interest that gave birth to the doctrime and has sustamed its use. However, the uniqueness of the facts of Rosenfeld and Detroit Free Press suggests that this more aggressive use of the central purpose doctrine will not be rephicated in other cases. ${ }^{174}$ Indeed, in Detroit Free Press, the

172. Id. at 98.

173. See United States Dep't of Defense v. Federal Labor Relations Auth. $114 \mathrm{~S}$. Ct. 1006, 1013-14 (1994) (rejecting derivative-use rationale concerning the disclosure of federal agency employees' hone addresses); see also supra note 44.

174. But see The Nation Magazine v. United States Customs Service, 71 F.3d 885 (D.C. Cir. 1995) (employing the central purpose doctrine to reverse a lower court order that refused to release Customs Service memoranda concerning an offer by Ross Perot to help finance the agency's interdiction of drug smuggling in the Caribbean). The decision in The Nation did not go as far as Rosenfeld or Detroit Free Press in using the ceutral purpose doctrine to require the disclosure of government information. Instead, the court in The Nation remanded the case for the lower court to conduct the public interest/private interest balancing test. $I d$. at 896.

The case is noteworthy, nevertheless, for its forthright adherence to the interests in favor of disclosing governunent information. The case involved a FOIA challenge to the Customs Services' categorical rule of refusing to release any of its law enforcement records concerning an individual unless the third-party requester had the consent of the person named in the records, who in this case was Ross Perot. The Customs Service argued that release of such records always would constitute an unwarranted invasion of privacy because the records concerned individuals, not the activities of the agency. The 
court emphasized that its decision was limited by the extremely specific facts of the case. ${ }^{175}$ The Supreme Court has not yet been forced to announce explicitly its position with respect to the derivative-use rationale. If similar cases ever reach the Court, ${ }^{176}$ it may be forced to reveal explicitly what las been implicit for many years-that the Court is loostile to arguments favoring broad access to government information.

\section{The States Take a Different Approach}

Each of the federal cases discussed so far addressed a statute that nominally was aimed at making public access to information a preeminent national policy. As the cases demonstrated, however, federal courts have construed FOIA in a way that displaces accessibility as the paramount goal. Instead, privacy has become the effective watcliword of FOIA jurisprudence today. A person seekmg information from the government cannot simply ask for it. Today, the requester must be prepared to show that the information is not about particular private citizens, but rather that it will directly reveal the government's activities. The requester next has the burden of showing that no one else's privacy-construed as broadly as the courts will dare-will be harmed by the disclosure of the information.

This tendency to value privacy over access is all the more noteworthy because some states have shown a contrary trend in recent amendments to their public records laws. These amendments exhibit a willingness to favor disclosure over privacy in the perennial battles for public access to information in a

D.C. Circuit, however, rejected this argument: "[T]he mere fact that records pertain to an individual's activities does not necessarily qualify them for exemption. Such records may still be cloaked with the public interest if the information would shed light on agency action." Id. at 894-95. The court then pointed out that the records in this case very clearly pertained to the activities of the Customs Service:

Appellants want to find out whether Perot offered to help a federal agency fulfill its statutory duties to interdict drugs, and if so, how that agency responded to his overtures. ... These concerns are about "agency activity," not just Perot's private activities. As such, their disclosure may serve the public's interest in knowing "what their government is up to."

Id. at 895 (quoting United States Dep't of Justice v. Reporters Comm. for Freedom of the Press, 489 U.S. 749, 773 (1989)).

175. See Detroit Free Press, 73 F.3d at 97.

176. The Court dismissed the Government's petition for certiorari in Rosenfeld. United States Dep't of Justice v. Rosenfeld, 116 S. Ct. 833 (1996). As of April 15, 1996, the Government had not filed a petition for certiorari in Detroit Free Press. 
government's files. ${ }^{177}$ These amendments articulate a belief that a person's right of access to information is based on the person's role as a sovereign over the government, as an owner of the government and its information. Furthermore, many of these amendments come packaged with provisions that greatly expand the scope of access to electronic information stored in the government's computers - the very kind of information access feared the most by advocates for greater privacy protection. ${ }^{178}$

177. Of course, comparison of FOIA with state public records statutes around the country necessarily involves contrasts between apples and oranges. For example, none of the state statutes involved here address concerns about national security or foreign diploinacy.

In addition, the discussion infra, part IV, will address statutes for the most part, rather than judicial decisions. This clooice to focus on statutes rather than judicial decisions could be faulted because in soine states, the public records statutes have been interpreted as favoring privacy over disclosure, in inuch the same way federal courts have interpreted FOIA. See Almeida v. Freedom of Info. Comm'n, 664 A.2d 322 (Coun. App. C. 1995) (reversing on privacy grounds a commission decision that had ordered the disclosure of infornation about an investigation of an altercation on school property); Hoy v. Kentucky Indus. Revitalization Auth., 907 S.W.2d 766 (Ky. 1995) (reversing on privacy grounds state attorney general's decision requiring disclosure of infornation submitted by corporation for investment tax credits); Edward A. Sherman Pub. Co. v. Carpender, 659 A.2d 1117 (R.I. 1995) (refusing on privacy grounds to release the names of school teachers who had received layoff notices bnt were not actually laid off).

With respect to the statutes discussed infra in text accoinpanying notes 179-227, however, such a favoring of privacy over disclosure seems unlikely because of the forthright philosophy announced in the very language of the new amendments. The statutes clearly place the interests of access and disclosure ahead of the interest in privacy. Thus, these state statutes will be examined not so much for their specific details as for the philosophy they exhibit. The goal is to ascertain whether these state laws offer a coherent alternative to the tendencies of the federal FOIA jurisprudence.

178. See, e.g., Cate et al., supra note 7, at 66-67 (arguing that extending FOIA access to computerized records would increase agency costs "exponentially" and would exacerbate "significant" invasions of privacy).

In addition to the state public records amendments discussed infra, text accompanying notes 186-215, several other states also expanded pnblic access to computerized information in 1995. See Act of June 15, 1995, 1995 Fla. Laws ch. 296 (to be codified in scattered sections of FLA. STAT. chs. 119 \& 282) (authorizing state officials to provide remote computer access to government information); N.D. CENT. CODE § 54-44.2 (1995) (authorizing state agencies to provide computer access to government information); Oregon Public Access Act of 1995, 1995 Or. Laws ch. 614 (declaring that electronic access to the Legislative Assembly will allow broader participation in the legislative process and in the establishment of procedures for publishing legislative material in electronic formats); TEX. GOV'T CODE ANN. § 552.228 (West Supp. 1996) (providing for electronic access to all otherwise public government infornation). 


\section{A. Indiana's 1995 Amendments}

In the Indiana legislature, political momentum to enact changes that would provide greater access to government information began to build in 1993. At that time, the Democratic leadership of the state House of Representatives stymied efforts by journalists at the Indianapolis Star and Indianapolis News to obtain records of the roll call votes on amendments to the 1993 budget bill. ${ }^{179}$ The confrontation led the newspapers to file suit under Indiana's Access to Public Records Law, ${ }^{180}$ seeking a court order forcing the House leadership to release copies of the roll call votes. ${ }^{181}$ The leadership, however, sought an interlocutory writ of prohibition from the Indiana Supreme Court barring the lower state court from proceeding any further on the suit. ${ }^{182} \mathrm{~A}$ divided court agreed with the House leadership, holding that any effort by the judiciary to enforce the Access to Public Records Law against the legislature "transgresses the ... separation of powers clause of our state constitution."183

The controversy did not end with the court's abdication on the issue. Instead, the Indiana Republican Party made the issue of public access to government information one of its planks im its "Contract with Indiana," promising to make records of legislative votes publicly available. ${ }^{184}$ When the Republicans swept control of the House, they announced that they would ensure that all roll call votes were treated as public records, available to anyone who asked for the information. ${ }^{185}$

The moinentum in favor of providing more public access did not stop with this change in the House's internal rules. In addition, the state legislature passed a comprehensive ineasure that ensures widespread access to electronic information in the computers of state and local government entities. ${ }^{186}$ The legislation ini-

179. See Russ Pulliam, A Sweep for the GOP?, InDIANAPOLIS NEws, Oct. 12, 1994, at A16 (describing the history behind the battle over public access to legislative voting records).

180. IND. CODE ANN. § 5-14-3 (Burns 1994 \& Supp. 1995).

181. See State ex rel. Masariu v. Marion Superior Court No. 1, 621 N.E.2d 1097 (Ind. 1993) (issuing the writ on a 3-2 vote).

182. Id. at 1098 .

183. Id.

184. See Pulliam, supra note 177 , at A16.

185. The Public Trust, Indianapolis STAR, Dec. 4, 1994, at D2 (commenting on GOP plans to ensure that records of roll call votes are made public).

186. See IND. Code ANN. § 5-14-3-1 et seq. (Burns Supp. 1995). 
tially encountered opposition from local government officials who argued that increasing public access through the use of computers would increase demands on staff time. ${ }^{187}$ The central opposition to the measure, however, involved complaints that the bill would prevent local governments from using their vast collections of data, such as real estate transactions, busmess hicenses, and court filings, as profit centers. ${ }^{188}$ The proponents of the measure argued that local governments should not be allowed to make a profit from information that had been collected at taxpayer expense; to do so would be "tantamount to a tax increase."189 The Indianapolis Star argued on its editorial page that the opponents of the measure "forget that the public, through our taxes, has already paid for the collection of the data. They forget that the public owns the data. They forget that public records are exactly what they say they are: public records." 190

The 1995 amendments resolved these arguments by allowing government entities to charge $105 \%$ of the combined total of three expenses: (1) the cost of "imitial development" of a program to retrieve electronic data; (2) the cost of the labor involved in actually retrieving the data; and (3) the cost of whatever diskette, tape, drum or other medium is used to store the copied information. ${ }^{191}$ This legislation allows government officials to make a modest five percent profit on the costs of searching and retrieving the electronic information. This portion of the bill represents a break from Indiana's earher provisions regarding fees for public records. The original Access to Public Records Law prohibited public agencies from charging any fee "[t]o inspect a public record; or [t]o search for, examine, or review a record to determine whether the record may be disclosed."192 The legislature's shift in public policy was an attempt to answer the protests from governinent officials about the costs of creating the coinputer software that would provide the electronic access required under the 1995 Amendments. ${ }^{193}$ More than just a political decision, this change in policy has legal implications because it might suggest that the

187. The Public's Records, INDIANAPOLIS STAR, Feb. 15, 1995, at A8.

188. Virtual Courthouse Square, INDIANAPOLIS NEWS, Feb. 16, 1995, at A8.

189. Id.

190. The Public's Records, supra note 187, at A8.

191. IND. CODE ANN. § 5-14-3-2 (Burns Supp. 1995) (definition of "direct cost").

192. IND. CODE ANN. § 5-14-3-8(b) (Burns Supp. 1995).

193. See The Public's Records, supra note 187, at A8. 
legislature views the government as the owner of the electronic information. ${ }^{194}$ If the legislation is intended to provide governments with a profit from the electronic information, then perhaps the government, and not the public at large, owns the information.

However, another change wrought by the 1995 aniendnients denionstrates that even though government agencies inay earn a profit on some computerized data disclosures, the legislature did not intend to recast the fundamental ownership rights of governinent information. The 1995 amendments append a new statement of "Public Pohicy" at the beginning of the Act ${ }^{195}$ in a dramatic affirmation of the notion that public records are owned by the public. Indiana's first incarnation of its Access to Public Records Law had declared that the "fundamental philosophy" of representative government in America is that "government is the servant of the people and not their master" and that "all persons are entitled to full and coinplete information regarding the affairs of government."196 The 1995 amendinents elaborated on this fundamental philosophy: "Providing persons with the information is an essential function of a representative government and an integral part of the routine duties of public officials and einployees, whose duty it is to provide the information."197

This elaboration underscores the view of the Republican inajority in the House of Representatives that providing access to government information-even information that arguably contains private details about individual citizens ${ }^{198}$-is part of the social contract of a representative government. ${ }^{199}$ As representatives of the people, government officials stand essentially as bailees of the information located in the government's files; the officials are

194. Indiana previously allowed a fee for copying paper records of ten cents per page or the average actual cost, whichever is greater. See IND. CODE ANN. § 5-14-3-8 (Burns 1994). This fee for copying-as opposed to searching and retrieving-government information probably is more than the actual cost to the government agency of providing the copy. Thus, even under the existing provisions for copying paper records, Indiana allowed government agencies to earn a small profit. The significant change in the 1995 Amendinents, however, involved allowing government agencies to earn a small profit merely for searching for coinputerized records.

195. See IND. CODE ANN. \& 5-14-3-1 (Burns Supp. 1995).

196. IND. CODE ANN. \& 5-14-3-1 (Burns 1994).

197. IND. CODE ANN. § 5-14-3-1 (Burns Supp. 1995).

198. Indiana's public records law includes a series of discretionary exceptions to the access provisions that protect personal privacy and other confidentiality concerns. See IND. CODE ANN. § 5-14-3-4(b) (Burns 1994).

199. See The Public Trust, supra note 185 , at D2. 
duty-bound to turn over the information to the public, the bailor, upon request. Because government officials liave a "duty" to provide the information to the public, a particular legal relationship arises between the government and the public. The legislature implicitly has established property riglits over government information, with the public as its owner and the government as its caretaker.

\section{B. North Carolina's 1995 Amendments}

A more dramatic statutory enactment of property rights occurred when the North Carolina General Assembly rewrote portions of the state's Public Records Law, and included a first-ever declaration of legislative policy. ${ }^{200}$ The 1995 amendments came just one year after the legislature had rewritten the state's Public Meetiugs Law, ${ }^{201}$ and the two measures were seen as twin pillars of an overarching effort to provide more access to government information. ${ }^{202}$

The original Public Records Law never declared an explicit policy in favor of access. Until the 1995 amendments, North Carolina was one of the twenty-six states that lacked a formal declaration of legislative intent in its public records laws. ${ }^{203}$ The General

200. Act of July 10, 1995, 1995 N.C. Sess. Laws ch. 388 (codified at N.C. GEN. STAT. $\S 132-1$ to -10$)$.

201. See Act of June 23, 1994, 1994 N.C. Sess. Laws ch. 570 (codified at N.C. GEN. STAT. § $143-318.9$ to 318.20 ).

202. See J. Andrew Curliss, New Law Makes Public Records More Accessible, News \& OBSERVER (Raleigl, N.C.), July 12, 1995, at A3.

203. Every state has some form of public records law. See FrankLIN \& BOUCHARD, supra note 22, at "State Statutes Appendix" (reproducing the public records laws of the 50 states and the District of Columbia).

The various formal declarations of legislative intent in the public records laws of 24 states and the District of Columbia may be found in the following statutes: ARK. CODE ANN. § 25-19-102 (Michie 1987 \& Supp. 1995); CAL. GOV'T CODE \& 6250 (West 1980 \& Supp. 1995); Colo. Rev. StAT. ANN. \& 24-72-201 (West 1988 \& Supp. 1995); DEL. CODE ANN. tit. 29, \& 501 (1991 \& Supp. 1994); D.C. CODE. ANN. \& 1-1521 (1992 \& Supp. 1995); FLA. STAT. ANN. \& 119.01 (West Supp. 1995); HAw. REV. STAT. § 92F-2 (1988 \& Supp. 1995); Ill. ANN. STAT. ch. 5, II 140/1 (Smith-Hurd 1993); IND. CODE ANN. § 5-14-3-1 (Burns 1994); KAN. STAT. ANN. § 45-216 (1993); ME. REV. STAT. ANN. tit. 1, \& 401 (West 1989); MD. CODE ANN., STATE GoV'T § 10-612 (1993); MICH. COMP. LAWS ANN. \& 15.231 (West 1994); MO. ANN. STAT. \& 610.011 (Vernon 1988); N.H. REV. STAT. ANN. § 91-A:1 (1990); N.J. STAT. ANN. § 47:1A-1 (West 1989); N.Y. PUB. OFF. LAW \& 84 (McKinney 1988); OKLA. STAT. ANN. tit. 51, § 24A.2 (West Supp. 1995); R.I. GEN. LAWS § 38-2-1 (1990); TEX. GOV'T CODE ANN. § 552.001 (West 1994); UTAH CODE ANN. § 63-2-102 (1993); VT. STAT. ANN. tit. 1, § 315 (1985); VA. CODE 
Assembly remedied this omission by adding a second section to the definition of a public record in the Public Records Law:

The public records and public information compiled by the agencies of North Carolina government or its subdivisions are the property of the people. Therefore, it is the policy of this State that the people may obtain copies of their public records and public information free or at minimal cost unless otherwise specifically provided by law. As used herein, "Ininimal cost" shall inean the actual cost of reproducing the public record or public information. ${ }^{204}$

In this short provision, the North Carolina General Assembly has defined the legal position of government information, declaring it to be the "property of the people." No other state im the country has a similar expression of public information rights. No other state has declared so explicitly that government information does not "belong" to the people who process it, but ratlier it belongs to all the people. Here, then, is a striking announcement of the underlying social purpose for access to government information. The legislature has declared that a person's access to government information will not be restricted solely to information that will reveal what the government is "up to." Instead, an individual may have access to compilations of information about other people, other businesses, other events-all the information the government maintains in its vast information warelıouses. ${ }^{205}$ The implications

ANN. § 2.1-340.1 (Michie 1995); WASH. REv. CODE ANN. § 42.17.251 (West 1991); W. VA. CODE § 29B-1-1 (1992).

An example from Oklahoma provides a sample of the kind of rhetoric used in these legislative declarations:

[A]ll political power is inherent in the people. Thus, it is the public policy of the State of Oklahoma that the people are vested with the inherent right to know and be fully informed abont their government. The Oklahoma Open Records Act shall not create, directly or indirectly, any rights of privacy or any remedies for violation of any rights of privacy.... The purpose of this act is to ensure and facilitate the public's right of access to and review of government records so they may efficiently and intelligently exercise their inherent political power.

OKLA. STAT. ANN. tit. 51, § 24A.2 (West Supp. 1995).

204. Act of July 10, 1995, 1995 N.C. Sess. Laws ch. 388, $\S 1$ (codified at N.C. GEN. STAT. § 132-1(b) (1995)).

205. As is the case with Indiana's public records law, the North Carolina statute also includes a series of provisions protecting privacy and other confidentiality concerns. See N.C. GEN. STAT. \$§ 132-1.1 to -1.4 (1995). These exceptious, however, are not based on the notion underlying the central purpose doctrine, i.e., information that does not shed light on government activities is not disclosable. Instead, these exceptions apply specifi- 
of this legislative policy are far-reaching: A person's rights of access appear to stem from his position as an owner of the information. He is entitled to the information not because it will help him be a better citizen in the body politic, but because le owns it.

The establishinent of a statutory property riglit in the 1995 amendments might have been nothing inore than hortatory rhetoric on the part of the General Assembly were it not for several other changes in the measure. For example, the legislation encourages government agencies to provide access at little or no cost, and to do it "as promptly as possible." These changes make clear that the General Assembly does not intend to allow government agencies to turn their collections of information into profit centers. Unlike the provisions in the Indiana amendments, the Nortlı Carolina amendments prevent government agencies from making any kimd of profit on the retrieval and copying of government information, in either paper or electronic form. ${ }^{207}$ The North Carolina amendinents require that the only fees that may be cliarged for copying records are those costs over and above what "would lave been mcurred by the public agency if a request to reproduce a public record liad not been made.,208 As state Sen. Roy Cooper, the Democratic sponsor of the 1995 amendments, said, "Open government is the foundation of freedoin. . . . All we have done is make sure the taxpayers have access to public records they liave already paid for."209

Another important legal principle lies buried in the new policy statement of the 1995 amendments. The records available under the law also imclude information that is "compiled" by government

cally to certain government activities, such as confidential communications by an agency's legal counsel to the agency's board, Id. $\S 132-1.1$; confidential trade secrets given to an agency in the course of contract work, Id. $\$ 132-1.2$; legal settlements by public agencies, but only wheu an overriding interest in confidentiality requires it, Id. § 132-1.3; and some law enforceinent records. Id. § 132-1.4.

206. Act of Inly 7, 1995, 1995 N.C. Sess. Laws ch. 388, §§ 1, 3 (codified at N.C. GEN. STAT. §§ 132-1(b) \& -6(a) (1995)).

207. The 1995 amendments include a limited exception to this principle of free or "actual cost" public access. When dealing with specialized "geographical information systems" (G.I.S.) operated by cities and counties, local governments may charge a "reasonable cost" for written or electronic copies of the databases. See id. \& 5 (codified at N.C. GEN. STAT. \& 132-10 (1995)). These G.I.S. databases are used by municipal planners to collate and process complex collections of demographic, geological, and land use information.

208. Id. $\S 3$ (codified at N.C. GEN. STAT. § 132-6.2(b) (1995)).

209. See Curliss, supra note 202, at A3. 
entities. ${ }^{210}$ Thus, the definition of a "public record" has been elaborated to mean more than just the documents or materials that have been "made or received" by state or local agencies. ${ }^{211}$ Under the 1995 amendments, the Public Records Law now clearly applies to collections of such public records that liave been gatliered together. For example, the Public Records Law now reaches not just the singular record of a person's arrest, ${ }^{212}$ but also any compilations of such arrests that are kept in a government agency's computers. ${ }^{213}$

This recognition of the public interest in compilations of government information is noteworthy because Nortl Carolina law provides privacy protections that are similar in soine ways to the privacy protections of the federal FOIA. ${ }^{214}$ Contrary to the suggestion of the U.S. Supreme Court, ${ }^{215}$ the North Carolina General Assembly has determined that the disclosure of government compilations of government information is in the public interest. North Carolina has determined that the interest in disclosure deserves more weight than the interest in privacy because, in the end, the information belongs to the people.

210. Act of July 7, 1995, 1995 N.C. Sess. Laws ch. 388, § 1 (codified at N.C. GEN. STAT. \& 132-1(b) (1995)).

211. See N.C. GEN. STAT. \& 132-1(a) (1995).

212. See id. § 132-1.4(c).

213. But cf. United States Dep't of Justice v. Reporters Comm. for Freedom of the Press, 489 U.S. 749 (1989) (holding that FBI compilations of criminal history information are categorically excluded from disclosure under FOIA).

214. Compare 5 U.S.C. §§ 552(b)(4) \& (6) (1994) (preventing disclosure of confidential commercial information, as well as personnel, medical or similar information that would constitute a clearly unwarranted invasion of privacy) with N.C. GEN. STAT. § 132-1.2 (1995) (excluding from the scope of the Public Records Law any information that is a trade secret under state law and is disclosed to a government agency in connection with a public contract or a bid for a public contract) and N.C. GEN. STAT. § 126-22 (1995) (excluding from the scope of the Public Records Law the persounel files of state enployees). But see N.C. GEN. STAT. § 126-23 (1995) (requiring state agencies to nuaintain separate public records for all employees listing the employees' name, age, date of hire, current salary, amount of most recent cliange in salary, and date of most recent change in employment status).

215. See Department of Justice v. Reporters Comm. for Freedom of the Press, 489 U.S. 749, 780 (1989) ("[W] pilation, rather than as a record of 'what the Government is up to,' the privacy interest ... is in fact at its apex while the FOIA-hased public interest in disclosure is at its nadir.") (emphasis added). 


\section{Georgia's 1995 Amendments}

In 1995, the Georgia legislature came full circle from the privacy rationale that had animated the Supreme Court's decision im Reporters Committee, deciding for itself that certain compilations of criminal information "rap sheets" were exactly the kind of information the public ought to liave. ${ }^{216}$ In so doing, the legislature provided strong evidence that when concerns of public peace and safety are at issue, the public has a right to as inuch information as the government can provide, regardless of whether this information concerns what the government is "up to" or instead concerns the affairs of individual citizens.

The 1995 amendinents revise the procedures regulating the Georgia Crime Information Center, opening public access to the criminal history information of all $\mathrm{m}$-state felony convictions and sentences compiled in the state's law enforceinent database. ${ }^{217}$ Under the old access provisions of the Georgia Crime Information Center, private persons and businesses could gain access to the state-wide database of criminal histories only if they supplied the fingerprimts or notarized consent of the person whose records were to be searched. ${ }^{218}$ Of course, an energetic investigator still could liave acquired the individual records without the person's consent by going to eacli one of the state's individual county courthouses where such records are kept. If a person wanted the convenience of a single clieck of all records across the state, liowever, the only way to get the information was under the regulations of the Crime Information Center.

The new alnendinents, however, provide access to auyone with $\$ 20$ to speud on each check of a person's records. ${ }^{219}$ In an acknowledgment of the heightened privacy concerns $m$ this area of public access law, the General Assembly incorporated a number of provisions, not the least of which is the fee requirement, that will ensure the ainendinents will not be used to request large sets of data froin the Crime Information Center. The amendinents require that the requester provide "identifying information ... sufficient

216. See Act of April 18, 1995, $1995 \mathrm{Ga}$. Laws 332 (codified at GA. CODE ANN. §§ 35-3-34 \& 35-3-35).

217. See id.

218. See GA. CODE ANN. § 35-3-34(a)(1) (1994).

219. See Act of April 18, 1995, 1995 Ga. Laws 332, art. 2 (codified at GA. CODE ANN. § 35-3-34(d.2)-(d.3)). 
to identify [the] persons whose records are requested."220 Furthermore, the amendinents include no provision for allowing the requester to obtain the data in electronic form. ${ }^{221}$

Despite these limitations, the Act is a startling break froin the jurisprudence that informed Reporters Committee. The Court in Reporters Committee had noted that forty-seven states place "substantial restrictions" on the availability of criminal history records. ${ }^{222}$ The Court said this pattern of treatınent by the states would not control the Court's determination of the scope of the federal FOIA ${ }^{223}$ but the Court argued that these state policies "provide evidence that the law enforcement profession generally assumes ... that individual subjects have a significant privacy interest in their criminal histories."224 The Court concluded that it was reasonable to believe that "Congress legislated with an understanding of this professional point of view."225

The Georgia General Assembly was fully aware of this "professional point of view" when it went in an entirely different direction. Under the 1995 amendments, the Georgia legislature has nade a policy clroice to favor disclosure-albeit limited disclosure-over privacy. For Georgia, the invasion of privacy that would follow the disclosure of records of in-state, felony convictions is not unwarranted. The legislature has determined that the disclosure is warranted by the public interest in peace and safety, in benig able to know another person's criminal history. The legislators appear to lrave decided that the release of criminal information histories is not categorically an unwarranted invasion of privacy. ${ }^{226}$ Instead, they have found that the disclosure of such information advances the government interest in an informed public. ${ }^{227}$ They have rejected the notion that the only information

220. Id.

221. See id.

222. Reporters Committee, 489 U.S. at 753.

223. Id. at 767 .

224. Id.

225. Id.

226. But $c f$. id. at 780 ("[W]e hold as a categorical matter that a third party's request for law enforcement records or information about a private citizen can reasonably be expected to invade that citizen's privacy, and ... the invasion of privacy is 'unwarranted."').

227. Several other states have recognized a similar public interest in making public the details of a sex offender's criminal history, following the lead of New Jersey's so-called "Megan's Law." See Sex Offender Laws Require Notification: 'Megan's Law,' Other Rules Face Constitutional Challenges, NEwS MEDIA \& L., Spring 1995, at 4, 5-6 (surveying 
properly subject to public disclosure is information that sheds light on what the government is "up to." Instead, they have determined that at least in this case, the information that is warehoused in the government's computer files should be disclosed for the sake of disclosure.

\section{A "Novel Legal QUestion"-The COllision Of FOIA AND STATE PUBLIC RECORdS LAwS}

As evidenced by the preceding discussion, some states recently have taken a substantially more expansive approach to the recurrimg struggle between disclosure and privacy than the federal courts. These states have weighed the competing interests and lave favored accessibility. What happens, however, when these principles of greater accessibility collide with the restrictive views of federal FOIA jurisprudence? The Sixth Circuit Court of Appeals faced this very conundrum, but the judges declined to resolve it. ${ }^{228}$

In United States $v$. Owens, the judges reviewed a conflict between Ohio's public records law ${ }^{22}$ and the FOIA Exemptions 3 and $7 . .^{230}$ The background of the Owens case began with the murder of the postmaster of Elgin, Ohio. ${ }^{231}$ Agents from the federal Office of the Postal Inspector and the FBI jomed officers from the Ohio State Police and the local police agencies to investigate the murder, eventually arresting and convicting Jolin G. Spirko Jr. ${ }^{232}$ During Mr. Spirko's trial, his lawyer sought access to the records of the investigation that were stored in locked filing

affirmative disclosure laws for felony crime offenders in Alaska, California, Louisiana, and Wisconsin); see also Doe v. Poritz, 662 A.2d 367 (N.J. 1995) (upholding the constitutionality of "Megan's Law," including the provisions requiring community notification and public disclosure of the names and home addresses of sex offenders upon finding that the government interest in disclosure outweighed the privacy interest).

Moreover, New Jersey Attorney General Deborah Poritz has begun a policy to expand access to all in-state criminal information records by allowing any person to obtain such records from the New Jersey State Police for a $\$ 27$ fee. See Kathy B. Carter, Putting a Price Tag on Criminal Records, STAR-LEdGer (Newark, N.J.), May 6, 1995, 1995 WL 5223765 , at $* 1$.

228. See United States v. Owens, 54 F.3d 271 (6th Cir.), cert. dismissed, 116 S. Ct. 492 (1995).

229. OHIO REv. CODE ANN. § 149.43 (Baldwin 1994).

230. See 5 U.S.C. \$ 552(b)(3), (7) (1994).

231. Owens, 54 F.3d at 273.

232. Id. at $271,273$. 
cabinets in a jail cell of the Van Wert County Sheriff's Office. ${ }^{233}$ In response to the pretrial discovery request, some of the investigatory documents were released, but in 1987, Mr. Spirko filed a FOIA request with the Postal Service for all of the documents. ${ }^{234}$ The Postal Service refused to release the files, and when Mr. Spirko filed suit in federal court, the Postal Service argued that the records fell under Exeinption $3^{235}$ because the Postal Reorganization Law specifically requires the Postal Service to withhold investigatory records. ${ }^{236}$ The magistrate who heard the case ruled in favor of the Postal Service, dismissing Mr. Spirko's complaint. 237

Mr. Spirko did not appeal this decision. Instead, he filed suit in Ohio state court against the Van Wert County Sheriff, seeking a writ of mandamus to compel the release of the files. ${ }^{238}$ Relying on the provisions of the state public records law, the Ohio Court of Appeals ordered the release in an unreported 1992 decision. ${ }^{239}$

With a writ of mandamus pending against the sheriff's office, the Postal Service then filed suit in federal court to enjoin the execution of the writ. ${ }^{240}$ The Postal Service now argued that FOIA applied to the records in the sheriff's office, and it preempted any broader access riglits under Olio's public records law. ${ }^{241}$ The district court agreed with the Postal Service and issued a permanent injunction against the enforcement of the state court order to release the investigatory files. ${ }^{242}$

233. Id. at 273 .

234. Id.

235. 5 U.S.C. $\& 552(b)(3)$ (1994) (allowing an agency in certain circumstances to withhold information that is "specifically exempted from disclosure by statute (other than section 552b of this title)").

236. Owens, 54 F.3d at 275.

237. Id. at 273 .

238. Id.

239. Id. The relevant provisions of Ohio's public records law require the release of law enforcement investigatory records if the records do not have a "high probability of disclosure" of any of the following: the identity of an uncharged suspect or confidential witness; information that would disclose the identity of a confidential witness; information abont confidential investigatory techniques; or information that would endanger the life or safety of law enforcement personnel, victims or witnesses. See OHIO REV. CODE ANN. $\S 149.43(\mathrm{~A})(2)$ (Baldwin 1994).

240. Owens, 54 F.3d at 273.

241. Id. at 273-74.

242. Id. at 274 . 
The Sixth Circuit did not address this issue directly in its decision; instead, the court remanded the case for further hearings because of procedural errors in the district court's permanent injunction order. ${ }^{243}$ The court noted that Mr. Spirko had raised nnaterial questions about which agency-the Postal Service or the sheriff's office-actually controlled the imvestigatory records stored in the jail-cell filing cabinet. Throughout the controversy the Postal Service had kept the keys to the file cabinets where the investigatory records were kept. The sheriff's office, however, apparently controlled access to the jail cell, including access by Postal Service agents. ${ }^{24}$ The district court may have assumed incorrectly that the Postal Service "led" the investigation. ${ }^{245}$ The Sixth Circuit concluded that "[a]t very least, it seems that Spirko has created a dispute as to whether the Postal Service has ownership, control, custody or possession of these records solely or jointly with the sheriff's office."246 Because of this question of material fact, the court ruled that the entry of a permanent imjunction was improper. The court vacated the district court's injunction and remanded for an evidentiary hearing at which Mr. Spirko would have an opportuuity to develop his case more fully. ${ }^{247}$

Chief Judge Merritt concluded the court's opimion by noting that if, on remand, "the district court were to find that the Postal Service and the sheriff's office have joint ownership, control, custody or possession of these records, that would create a novel legal question."248 This question is "novel" not merely because it would pose difficult issues of federalism and federal court jurisdiction. ${ }^{249}$ It is novel also because it would force the federal courts

\footnotetext{
243. Id. at 277.

244. Id.

245. Id.

246. Id.

247. Id.

248. Id.

249. The question of whether FOIA preempts state public records law is an issue beyond the scope of this Note. It is the author's view that FOIA would not necessarily preempt such state public records laws because there is no express preemption clause in FOIA aud because these state and federal laws are not in actual conflict. See Freightliner Corp. v. Myrick, 115 S. Ct. 1483, 1487 (1995) ("[A] federal statute implicitly overrides state law either when the scope of a statute indicates that Congress intended federal law to occupy a field exclusively ... or when state law is in actual conflict with federal law.") (citations omitted). But see Umited States v. Napper, 694 F. Supp. 897 (N.D. Ga. 1988) (ordering the city of Atlanta to return federal investigatory files to the Uuited States after the city had released some information in the files to news media pursuant
} 
to come to grips with the extent to which federal FOIA jurisprudence and state public access laws have diverged. Certainly, the fact that some states may have more generous access laws than Congress has fashioned for the federal agencies is not unusual. Yet the conflict in the Owens case is not really about a conflict between the texts of state and federal statutes. Indeed, the law enforcement exemption provisions of Ohio's public records law are sufficiently analogous to the provisions under FOIA's Exemption $7^{250}$ to suggest that the results in state and federal courts could have duphicated theinselves, but they did not.

The reason for the opposing results has more to do with the way federal courts have shaped FOIA than with any minor differences between FOIA and the state public records law. According to recent FOIA jurisprudence, especially the central purpose doctrine, the kind of records at issue in Owens should be disclosed only if the information "contribute[s] significantly to public understanding of the operations or activities of the government."251 The central purpose doctrine thus has ensured that very few law enforcement records ever will be released, except perhaps those records that mvolve mvestigations of the government itself. On the other hand, the primciples that have informed many state public records laws, such as Ohio's, mclude the notion that sometimes disclosure and access to information are a sufficient public interest in their own right. Although Ohio's public records law suggests that it too is concerned about privacy imterests, the statute also acknowledges that information in the government's files may be useful to citizens even though it reveals nothing about what a government has been "up to.".252

to a state court order under the state public records law), affd per curiam 887 F.2d 1528 (11th Cir. 1989).

250. Compare OHIO Rev. CODE ANN. $\S 149.43(\mathrm{~A})(2)$ (Baldwin 1994) (exempting from public access certain "confidential law enforcement investigatory records") with 5 U.S.C. § 552(b)(7) (1994) (exempting from access under FOIA certain records "compiled for law enforcemeut purposes").

251. Umited States Dep't of Justice v. Reporters Comm. for Freedoin of the Press, 489 U.S. 749, 775 (1989).

252. Ohio's public records law defines a public record as "any record that is kept in a public office." OHIO REV. CODE ANN. § 149.43 (A)(1) (Baldwin 1994). An example of information that is a public record under Ohio law even though it does not reveal what the government has been "up to" is a list of charitable donors to the state's universities. See State ex rel. Toledo Blade Co. v. Unversity of Toledo Found., 602 N.E.2d 1159 (Ohio 1992) (holding that such a list is a public record and is not exempt from disclosure under any exception in the public records law). 
Access to government information does not merely provide the keys to responsible citizenship in an informed republic. Access to information also ensures for the individual citizen a sense of empowerment and control over a government that can at times appear monolithic and imperious. The possession of a right to access government information places the citizen and the citizen's government in the proper posture with respect to their political relationship. Government information should be accessible to the public not merely because it will make the public more informed but also because the public owns it. If information is power, then to deny public ownership of government information is to deny public control over the government. The facts of Owens present a classic confrontation between this philosopliy of public ownership over government information and the central purpose doctrine. Owens also illustrates the problem with FOIA's central purpose doctrine-it tempts judges to ignore or undervalue the merits to society of free access to government information. Unfortunately, as the central purpose doctrine receives ever wider application, the judicial apphication of FOIA will continue to erode free access to government information.

\section{CONCLUSION}

The FOIA cases this Note discusses have highlighted a potent and robust central purpose doctrine that courts today apply far afield from the privacy exemptions whence it came. These cases present an overall picture of a federal judiciary intent on reining in citizen access to the information collected and compiled by the very federal agencies whose existence is paid for by these citizens. Whether the particular tool is a specific exeinption under FOIA or a reference to the "central purpose" of the Act, many federal courts lave tried to crank down the spigot of information. In contrast, several states have enacted recent amendments to their public records laws that encourage widespread access to government information and establish a paramount public policy of openness.

This divergence in philosophy has more than mere academic significance. The practical implications are dramatic. In some states, a person is far more likely to have success in prying information from his state or local government than froin federal officials. Thus, for example, a person in North Carolina will have 
more success getting access to government information from state officials than from federal officials if he wants know how much money is being paid to the landlords of federally subsidized, locally managed apartment housing. Under the state's public records law, the information is more freely available from the local housing agency that manages the program than from the federal agency that pays the money. Or, in another example, a person in Georgia who wants to know whether a serviceman at Fort Benning has a record of any felony sex assaults in the state would be better off getting the information from the state than from the Army. In either case, the same information is at issue. However, because of different philosophies about disclosing government information, the same level of accessibility is not available.

Access to information long has been one of the central bulwarks to a free democracy. James Madison said as much 174 years ago. ${ }^{253}$ Today, however, the bulwark faces erosion from the central purpose doctrine and its exaltation of privacy doctrines. As the Infornation Age speeds upon us, we would do well to remember words spoken in commemoration of one of the first battles that gave birth to our republic:

[T] he people have begun, in all forms of government, to think, and to reason, on affairs of state. Regarding government as an institution for the public good, they demand a knowledge of its operations, and a participation in its exercise. ... As knowledge is more and more extended, this conviction becounes more and more general. Knowledge, in truth, is the great sun in the firmament. Life and powers are scattered with all its beams. ${ }^{254}$

253. See Letter from James Madison to W.T. Barry (Aug. 4, 1822), reprinted in THE COMPLETE MADISON 337 (Saul K. Padover ed., 1953), quoted in Rees, supra note 51, at 1184 ("Knowledge will forever govern ignorance; And a people who mean to be their own Governors, must arm themselves with the power which knowledge gives.").

254. Daniel Webster, Address at the Laying of the Cornerstone of the Bunker Hill Monument, in Charlestown, Mass. (June 17, 1825), reprinted in 1 THE WRTINGS AND SPEECHES OF DANIEL WEBSTER 235, 250 (National Edition 1903). 